\title{
Aproximación a la Ley 7/2011 de documentos, archivos y patrimonio documental de Andalucía
}

\author{
Severiano Fernández Ramos \\ Catedrático de Derecho Administrativo \\ Universidad de Cádiz
}

SUMARIO: I. INTRODUCGIÓN. 1. Sobre la necesidad de una nueva Ley de Archivos. 2. Aspectos generales de la Ley 7/2011. II. LOS DOCUMENTOS DE TITULARIDAD PÚBLICA. 1. Documentos de titularidad pública y Patrimonio Documental de Andalucía. 2. Delimitación de los documentos de titularidad pública. 3. Régimen jurídico de los documentos de titularidad pública. III. EL PATRIMONIO DOGUMENTAL DE ANDALUCIA. 1. Concepto de Patrimonio Documental de Andalucía. 2. Documentos del Patrimonio Documental de Andalucía. A. Documentos de titularidad pública. B. Documentos de titularidad privada. 3. Régimen jurídico del Patrimonio Documental de Andalucía. A. Integridad del Patrimonio Documental de Andalucía. B. Deber de información. C. Derechos de tanteo y retracto. D. Otros deberes de los titulares y poseedores de documentos privados. E. Traslados de documentos de titularidad privada. F. Depósito forzoso. G. Expropiación forzosa y medidas de fomento. IV. EL SISTEMA ARCHIVÍSTICO DE ANDALUCíA. 1. Conceptos. 2. Órganos del Sistema Archivístico de Andalucía. A. Los órganos ejecutivos. B. Comisión Andaluza de Valoración y Acceso a los Documentos. C. Comisión del Sistema Archivístico de Andalucía. 3. Régimen de los archivos del Sistema Archivístico de Andalucía. 4. Archivos de la Junta de Andalucía. A. Clasificación de los archivos. B. El Archivo del Parlamento de Andalucía y los archivos de las instituciones de autogobierno. C. Los archivos centrales. D. Los archivos provinciales intermedios. E. Archivo General de Andalucía. F. Archivos Históricos Provinciales. 5. Otros archivos del Sistema Archivístico de Andalucía. A. Archivos de las entidades locales de Andalucía. B. Archivos de las universidades públicas de Andalucía. C. Otros Archivos. 6. El Censo de Archivos de Andalucía. V. LA GESTIÓN DOCUMENTAL. 1. Concepto y funciones de la gestión documental. 2. La gestión documental en la Junta de Andalucía. VI. EL ACCESO A LOS DOCUMENTOS. 1. Acceso a los documentos de titularidad pública. 2. Acceso a los documentos de titularidad privada. CONCLUSIONES. 


\section{RESUMEN:}

En este estudio se analizan las novedades que aporta la reciente Ley 7/2011, de 3 de noviembre, de Documentos, Archivos y Patrimonio Documental de Andalucía, la cual constituye una importante renovación de la ordenación del Patrimonio Documental de Andalucía, en que se insertan documentos de titularidad pública y de titularidad privada, así como del Sistema Archivístico de Andalucía (sus órganos y estructuras), así como supone la introducción del sistema de gestión documental y el reconocimiento de la relevancia actual del derecho de acceso a los documentos.

Palabras claves: Archivos. Documentos. Patrimonio Cultural. Acceso a la información pública.

\section{ABSTRACT:}

This study examines innovations that brings the recent law 7/2011, 3 November, documents, archives and documentary property of Andalusia, which constitutes a major renovation of the management of the documentary heritage of Andalusia, which inserted documents of public ownership and private ownership, as well as the Archivístico system of Andalucía, as well as the introduction of the document management system and the recognition of the current relevance of the right of access to documents.

keywords: Archives. Documents. Cultural property. Access to public information.

\section{INTRODUCGIÓN}

\section{Sobre la necesidad de una nueva Ley de Archivos}

Andalucía fue la primera Comunidad Autónoma en aprobar, ya en su primera legislatura, una ley de archivos: la Ley 3/1984, de 9 de enero, de Archivos (en adelante Ley 3/1094), que, por ende, fue la primera ley de archivos de nuestra historia. Asimismo, la Ley 3/1984 fue una norma pionera, pues concibió principios, criterios y técnicas que serían adoptados tanto por el Estado, en la Ley 16/1985, de 25 de junio, de Patrimonio Histórico Español (en adelante LPHE), como por la mayoría de las Comunidades Autónomas ${ }^{1}$.

\footnotetext{
${ }^{1}$ Ley de Cataluña 6/1985, de 26 de abril, de Archivos (derogada); Ley de Aragón 6/1986, de 28 de noviembre, de Archivos; Ley de Canarias 3/1990, de 22 de febrero, de Patrimonio Documental y Archivos; Ley de la Región de Murcia 6/1990, de 11 de abril, de Archivos y Patrimonio Documental; Ley de Castilla-León 6/1991, de 19 de abril, de Archivos y Patrimonio Documental; Ley de la Comunidad de Madrid 4/1993, de 21 de abril, de Archivos y Patrimonio Documental; Ley de La Rioja 4/1994, de 24 de mayo, de Archivos y Patrimonio Documental.
} 
Así, entre las innovaciones introducidas por la Ley 3/1984 cabe destacar las siguientes: la ordenación conjunta pero diferenciada del Patrimonio Documental, como parte integrante del Patrimonio Histórico, y de los Archivos, como instituciones ligadas a la conservación y difusión del Patrimonio Documental; la ampliación tanto del Patrimonio Documental de titularidad pública (documentos de Corporaciones de Derecho Público y de gestores privados de servicios públicos) como de titularidad privada (reducción significativa del plazo de integración en el PD de los documentos de ciertas entidades privadas que "realizan actividades de interés público"); la cuasi "demanialización" de los documentos de titularidad pública (pues se declaran inalienables, imprescriptibles e inembargables); el intento de articular un Sistema coherente de Archivos, integrado por todos los archivos de uso público de competencia autonómica, independientemente de su titularidad - autonómica, estatal, local o privada-, determinación que sería ratificada por el Tribunal Constitucional (STC 103/1988); o la primera ordenación legal del ejercicio del derecho de acceso a la documentación ${ }^{2}$.

Sin embargo, la experiencia ha demostrado que el planteamiento fundacional de la Ley 3/1984 de configuración de los archivos como instituciones culturales, vinculadas exclusivamente a la conservación y difusión de una faceta del Patrimonio Cultural, era excesivamente reduccionista del papel que los archivos públicos están llamados a desempeñar en el actual sistema de gestión administrativa y como garantía del principio de transparencia de la actuación pública. Además, en estos lustros de vigencia de la Ley 3/1984 han sido muchos y profundos los cambios normativos acaecidos en el ordenamiento jurídico, tanto estatal, como autonómico. Y en este contexto debe destacarse la renovación legislativa experimentada en el resto de leyes andaluzas relativas al patrimonio cultural, en especial, tras la aprobación de la Ley 14/2007, de 26 de noviembre, de Patrimonio Histórico de Andalucía ${ }^{3}$.

En todo caso, no ha supuesto en esta materia cambio significativo el nuevo Estatuto de Autonomía para Andalucía. En efecto, el Estatuto -art. 68.3- es-

\footnotetext{
${ }^{2}$ Véase FERNÁNDEZ RAMOS, Severiano: "La Ley de Archivos de Andalucía. Una experiencia", Revista Andaluza de Administración Pública, núm. extraordinario, 2/2003, Veinte años de vigencia del Estatuto de Autonomía de Andalucía. Desarrollo de las competencias autonómicas, Volumen I, pp. 235-269.

3 También debe destacarse que la contemporánea Ley 2/1984, de 9 de enero, de Museos, fue sustituida por la Ley 8/2007, de 5 de octubre, de Museos y Colecciones Museográficas de Andalucía. Y antes aún la Ley 8/1983, de 3 de noviembre, de Bibliotecas fue derogada por la Ley 16/2003, de 22 de diciembre, del Sistema Andaluz de Bibliotecas y Centros de Documentación. De este modo, la Ley 3/1984 de Archivos era la última ley en materia de patrimonio cultural por renovar.
} 
tablece que corresponde a la Comunidad Autónoma, la competencia exclusiva sobre archivos (museos, bibliotecas y demás colecciones de naturaleza análoga) que no sean de titularidad estatal. Asimismo, la Comunidad Autónoma asume competencias ejecutivas sobre los museos, bibliotecas, archivos y otras colecciones de naturaleza análoga de titularidad estatal situados en su territorio cuya gestión no se reserve el Estado, lo que comprende, en todo caso, la regulación del funcionamiento, la organización y el régimen de su personal -art. 68.2- ${ }^{4}$. Sin embargo, estas atribuciones no suponen una alteración sustancial de lo ya previsto en el Estatuto de 1981 -arts. 13.28 y 17.4-, el cual ya había agotado las posibilidades competenciales admitidas por la Constitución, la cual reserva al Estado la competencia exclusiva sobre archivos (museos y bibliotecas) de titularidad estatal, sin perjuicio de su gestión por las Comunidades Autónomas - art. 149.1.28 $\mathrm{CE}^{-5}$.

\section{Aspectos generales de la Ley $7 / 2011$}

El proyecto de Ley de Documentos, Archivos y Patrimonio Documental tuvo una cómoda tramitación parlamentaria ${ }^{6}$. De hecho, aun cuando fueron rechazadas las enmiendas tanto del Grupo Popular como del Grupo IU-Los Verdes, el Pleno del Parlamento aprobó el dictamen de la Comisión por unanimidad, quedando aprobada la que sería la Ley 7/2011, de 3 de noviembre, de Documentos, Archivos y Patrimonio Documental de Andalucía (en adelante Ley $7 / 2011)^{7}$.

\footnotetext{
${ }^{4}$ Además, el Estatuto añade que la Junta de Andalucía colaborará con el Estado a través de los cauces que se establezcan de mutuo acuerdo para la gestión eficaz de los fondos del Archivo de Indias y de la Real Chancillería - art. 68.4-. Véase sobre el artículo 68 del Estatuto, E. ARANA GARCÍA, «Competencias sobre cultura y patrimonio», Comentarios al Estatuto de Autonomía para Andalucía, Muñoz Machado y Rebollo Puig (Dirs.), Thomson-Civitas, Madrid, 2008, pp. 657 y ss.

${ }^{5}$ Sobre la distribución de competencias en materia de archivos y patrimonio documental, véase FERNÁNDEZ DE GATTA SÁNCHEZ, Dionisio: «La legislación sobre archivos: régimen vigente y retos futuros», Tabula, 10, Combates por la memoria: archivística de la posmodernidad, 2007, pp. 255 y ss.

${ }^{6}$ De entrada, el proyecto no recibió ninguna enmienda a la totalidad, por lo que superó sin problema alguno el debate de totalidad del proyecto. DSPA Plenos núm. 121, 8 de junio de 2011, pp. 20 y ss. Una vez admitido a trámite, el Grupo Popular formuló 54 enmiendas, de las cuales la inmensa mayoría eran meras propuestas de cambio de estilo, y en algunos casos se proponía una pequeña adición o modificación, pero sin llegar a constituir una modificación de calado ${ }^{6}$. Por su parte, el Grupo IU-Los Verdes se limitó a formular dos enmiendas de carácter circunstancial (referidas a impulsar la indagación de fondos documentales de entidades privadas y a negociar la cesión de fondos documentales del Estado generados en la Comunidad). Asimismo, el Grupo Parlamentario Socialista formuló apenas cuatro enmiendas (pues dos no tienen nada que ver con los archivos, se refieren a los conjuntos culturales). BOPA núm. 754. de 3 de octubre de 2011.

${ }^{7}$ DSPA Plenos núm. 133, 26 de octubre de 2011, páginas 6 a 12. El texto de la Ley se publicó en el BOPA núm. 776, de 4 de noviembre de 2011.
} 
De entrada, mientras la Ley 3/1984 llevaba por título de Archivos, la nueva ley incorpora a su título los Documentos y el Patrimonio Documental. Respecto a este segundo elemento, en realidad, ya la Ley 3/1984 era, sobre todo, una Ley de patrimonio documental y, de hecho, la mayoría de las Comunidades Autónomas que ordenaron con posterioridad a la de Aragón esta materia optaron por denominar a sus respectivas Leyes de Archivos y Patrimonio Documental. Por su parte, la adición del término Documentos se sitúa en la estela de la Ley de Cataluña 10/2001 de 13 de julio, de Archivos y Documentos, con la finalidad de realzar el régimen de una categoría específica de documentos: los documentos de titularidad pública. Y este triple objeto está explicitado en el artículo 1 de la Ley: «La presente ley tiene por objeto regular la gestión, la protección, el acceso y la difusión de los documentos de titularidad pública y del Patrimonio Documental de Andalucía, así como la coordinación, planificación, organización y funcionamiento del Sistema Archivístico de Andalucía», así como en el artículo 3.1 al delimitar su ámbito de aplicación: a) Los documentos de titularidad pública. b) El Patrimonio Documental de Andalucía. c) Los archivos que constituyen el Sistema Archivístico de Andalucía, con independencia de su titularidad $^{8}$.

Por lo demás, la Ley 7/2011 va a requerir de un ingente desarrollo reglamentario, pues la remisiones normativas son abundantes (arts. 11.1, 11.2, 12.2, $18,21.1,22.2,30,31.2,32.3,39.1,43.5,44.5,45,49.3,52.3,59,62.6,63.1$, entre otros), y que obligará a la renovación de la normativa reglamentaria vigente. Sin embargo, la ley no ha fijado plazo alguno para este imprescindible desarrollo normativo.

\section{LOS DOCUMENTOS DE TITULARIDAD PÚBLICA}

\section{Documentos de titularidad pública y Patrimonio Documental de Andalucía}

La Ley 3/1984, como el resto de las leyes autonómicas que vinieron después (hasta la Ley de la Comunidad Autónoma de Cataluña 10/2001) no se preocupó por deslindar una categoría autónoma de documentos de titularidad pública, sino que se limitó a delimitar los documentos que integraban el Patri-

\footnotetext{
${ }^{8}$ Si bien la Ley se ve obligada a añadir de inmediato que los archivos de titularidad estatal cuya gestión corresponda a la Comunidad Autónoma se regirán por la legislación estatal que les afecte, por los convenios suscritos entre el Estado y la Junta de Andalucía y por las disposiciones de esta ley, ordenación autonómica que debe ceñirse a los aspectos admitidos en el Estatuto de Autonomía, esto es «la regulación del funcionamiento, la organización y el régimen de su personal»-art. 68.2 Estatuto de Autonomía-
} 
monio Documental Andaluz, si bien de la ordenación de la Ley se desprendía una distinción entre los documentos de de titularidad pública en sentido amplio -arts. 2 y $3-$ y los documentos de titularidad privada -arts. 4.5 y $6-$, distinción que también se reflejaba en el régimen del Patrimonio Documental Andaluz establecido por la Ley 3/1984.

Por su parte, la Ley 7/2011 separa en su Título I de modo aparentemente radical las nociones de documentos de titularidad pública (Capítulo I) y de Patrimonio Documental de Andalucía (Capítulo II). Sin embargo, esta separación sólo es aparente, pues si bien el artículo 9 delimita la noción de documento de titularidad pública, el artículo 15.1.a) declara que forman parte del Patrimonio Documental de Andalucía los documentos de titularidad pública de cualquier época, recogidos o no en archivos, definidos en el artículo 9, es decir, todos los documentos desde el mismo el mismo instante en que se generan o reciben por cualquiera de los órganos y entidades relacionados en el artículo $9^{9}$. Por tanto, la categoría de documentos de titularidad pública ordenada en la Ley no es más que una clase de documentos integrantes del Patrimonio Documental de Andalucía. Por ello, habría sido más clarificador iniciar por el tratamiento del Patrimonio Documental de Andalucía, dentro del cual se encuentran todos los documentos de titularidad pública, para después pasar a las particularidades tanto de los documentos de titularidad pública, como de titularidad privada.

\section{Delimitación de los documentos de titularidad pública}

La Ley 3/1984 -arts. 2 y 3-amplió notablemente el ámbito de los documentos de titularidad pública integrantes del patrimonio documental. Por su parte, la Ley $7 / 2011$-arts. 2.b) y 9.1- declara que son documentos de titularidad pública los de titularidad de las personas físicas o jurídicas, tanto públicas como privadas, enumeradas en el apartado siguiente, producidos y recibidos en el ejercicio de las competencias que les son propias, sin perjuicio de la normativa estatal o internacional que les afecte. En concreto, se declaran documentos de titularidad pública los documentos de los órganos y entidades que siguen, y que, en lo sustancial, coincide con lo ya establecido en la Ley 3/1984, con las lógicas novedades derivadas de los cambios normativos acaecidos desde entonces:

\footnotetext{
${ }^{9}$ Por este motivo presenta una cierta incorrección el artículo 10 cuando establece: «Los documentos de titularidad pública que forman parte del Patrimonio Documental de Andalucía de acuerdo con el artículo 15.1.a) son inalienables, imprescriptibles e inembargables». Interpretado literalmente parecería desprenderse del precepto que hay documentos de titularidad pública que no forman parte del Patrimonio Documental de Andalucía. Para ser correcto, el artículo 10 debería establecer: «Los documentos de titularidad pública, que forman parte del Patrimonio Documental de Andalucía de acuerdo con el artículo 15.1.a), son inalienables, imprescriptibles e inembargables».
} 
a) «Los del Parlamento de Andalucía y demás instituciones de autogobierno de la Comunidad Autónoma reseñadas en el capítulo VI del título IV del Estatuto de Autonomía para Andalucía».

b) «Los de la Presidencia de la Junta de Andalucía y el Consejo de Gobierno».

c) «Los de la Administración de la Junta de Andalucía».

d) «Los de las entidades instrumentales de la Administración de la Junta de Andalucía». Aquí se encuentra la principal ampliación respecto a la Ley 3/1984, siguiendo el criterio de la LPHE, que incluyó a los documentos de las «personas jurídicas en cuyo capital participe mayoritariamente el Estado u otras Entidades públicas».

e) «Los de las corporaciones de derecho público de Andalucía, en lo relativo a sus funciones públicas atribuidas».

f) «Los de las entidades locales de la Comunidad Autónoma y sus entes, organismos o empresas de ellas dependientes» ${ }^{10}$.

g) «Los de las universidades públicas radicadas en Andalucía y centros y estructuras de ellas dependientes».

h) «Los de la Administración del Estado y sus organismos públicos, sociedades mercantiles y fundaciones de ella dependientes radicados en Andalucía» ${ }^{11}$.

i) «Los de los órganos de la Administración de Justicia radicados en Andalucía».

j) «Los de las notarías y registros públicos radicados en Andalucía».

k) «Los de los organismos dependientes de las instituciones de la Unión Europea, así como los de cualquier otro organismo público internacional radicados en Andalucía».

l) «Los de entidades dotadas de personalidad jurídica propia creadas, participadas mayoritariamente o controladas efectivamente por cualquiera de las entidades y personas jurídicas mencionadas en este artículo en el ejercicio de potestades administrativas o funciones públicas». Lo cierto es que estas entidades jurídico-privadas (y esta parece que es la intención, pues se habla de «entidades participadas mayoritariamente o controladas»), ya están incluidas en el apartado d), referido a las entidades instrumentales de la Administración de la Junta de Andalucía, de acuerdo con la noción de la LAJA - art. 52-, y en el apartado $e$ ) referido a las entidades locales de la Comunidad Autónoma «y sus entes, organismos o empresas de ellas dependientes». Pero, sobre todo, la Ley 7/2011 incurre en un error grave, pues la LAJA prohíbe terminantemente que entidades privadas ejerzan potestades públicas -art. $75.2-$.

\footnotetext{
${ }^{10}$ Sorprende que este precepto no utilice la terminología de la Ley 5/2010, de 11 de junio, de Autonomía Local de Andalucía -art. 33-, sobre todo cuando el artículo 49.2 de la propia Ley 7/2011 sí la emplea, al hablar de «entes vinculados o dependientes».

${ }^{11}$ La STC 103/1988, precisamente relativa a la Ley de Andalucía 3/1984, avaló esta inclusión.
} 
m)«Los de las personas privadas físicas o jurídicas gestoras de servicios públicos, en cuanto a los documentos generados en la prestación de dichos servicios».

n) «Los de las entidades dependientes de los organismos públicos y los de cualquier otra entidad pública no incluida en los supuestos anteriores en el ejercicio de potestades administrativas o funciones públicas».

No obstante, esta delimitación ha podido quedarse corta, pues existen entidades privadas que ejercen funciones inequívocamente públicas sin que medie concesión propiamente dicha y sin que puedan ser calificadas de entidades dependientes de los organismos públicos (como sucede con las entidades colaboradas en materia de control e inspección) ${ }^{12}$.

En definitiva, la delimitación de los documentos de titularidad pública, con una terminología más actualizada, coincide en lo sustancial con la ya establecida en la Ley 3/1984, pues la única novedad relevante es la inclusión de las entidades jurídico-privadas integrantes del sector público. De este modo, la Ley andaluza acoge una noción muy amplia de documentos de titularidad pública, no restringida a aquellos de titularidad de entidades jurídico-públicas, sino que abarca a los documentos en poder de entidades jurídico-privadas del sector público, más los documentos generados en la prestación servicios públicos por parte de personas privadas gestoras, noción que coincide con la seguida por la práctica totalidad de las leyes autonómicas.

\section{Régimen jurídico de los documentos de titularidad pública}

Ya la Ley 3/1984 declaró que los documentos de titularidad pública no podían ser enajenados, ni sometidos a traba o embargo, aun cuando, por la naturaleza de su titular, fuesen susceptibles de ello, y tampoco podían adquirirse por prescripción. Y esta prohibición de tráfico jurídico fue seguida por la generalidad de las leyes autonómicas que proclaman que los documentos de titularidad pública son inalienables, imprescriptibles e inembargables, propiedades propias -como es notorio- de los bienes de dominio público - art. 132.1 Constitución-. Por su parte, la Ley 7/2011 mantiene este criterio al declarar que los documentos de titularidad pública son inalienables, imprescriptibles e inembargables -art. 10.1-. Y, dado su carácter inalienable e imprescriptible, los documentos de titularidad pública, al igual que los bienes de dominio público, no pierden su naturaleza ni el régimen legal al que estén sujetos, cual-

\footnotetext{
12 De aquí que alguna Ley añada un apartado adicional relativo a las personas y las entidades privadas que ejercen funciones públicas, en lo que se refiere a estas funciones. Ley de Cataluña 10/2001 -art. 6.1-.
} 
quiera que sea su propietario, poseedor o detentador, de modo que el titular legal podrá reclamarlos en cualquier momento. Y, en este sentido, la Ley 7/2011 establece que la Junta de Andalucía podrá recuperar en todo momento la posesión de estos documentos cuando se hallen indebidamente en posesión de terceros, adoptando las medidas legales oportunas para conseguir su reintegro -art. 10.2-.

De otro lado, la Ley 7/2011 -art. 12.1- establece que las personas al servicio del sector público tienen la obligación de custodiar los documentos que tengan a su cargo. La custodia de documentos de titularidad pública conlleva la obligación de preservarlos. Esto supone sancionar tanto la pérdida, como la eliminación indebida de documentos de titularidad pública ${ }^{13}$. Asimismo, los documentos de titularidad pública solo podrán salir de sus correspondientes unidades administrativas, sistemas de información y archivos en los casos y con los procedimientos que se establezcan reglamentariamente, si bien a estos efectos, el préstamo administrativo y el requerimiento por órganos jurisdiccionales no se considerarán como salida ${ }^{14}$.

Además, la Ley 7/2011 -art. 12.3- establece que las personas responsables de los órganos administrativos, así como cualquier otra persona física que por razón del desempeño de una función en el sector público tenga a su cargo o bajo su custodia documentos de titularidad pública, deberán entregarlos al cesar en sus funciones a quien les suceda en el cargo, o, en su defecto, al archivo público que corresponda, precepto claramente inspirado en el artículo 54.1 LPHE $^{15}$.

\footnotetext{
13 Así, la Ley califica como infracción muy grave la eliminación de documentos de titularidad pública prescindiendo de los procedimientos reglamentariamente establecidos - art. 71.b)-, y como infracción grave la pérdida o desaparición de los documentos custodiados en archivos del Sistema Archivístico de Andalucía - art. 72.a)-.

${ }^{14}$ En este sentido, la reforma de la Ley 3/1984 efectuada por la Ley 14/2007 dispuso que no era necesaria la autorización en caso de préstamo administrativo - art. 37-. No define la Ley 7/2011 el préstamo administrativo. Puede recordarse que la Ley 3/1984, modificada por la Ley 14/2007, entendía por préstamo administrativo la entrega o remisión de expedientes o, en general, de documentos, a los órganos jurisdiccionales o administrativos en cumplimiento de lo dispuesto en el Ordenamiento Jurídico -art. $37.2-$, noción que parecía englobar la entrega a requerimiento judicial.

${ }^{15}$ Según el artículo 54.1 LPHE, quienes por la función que desempeñen tengan a su cargo documentos de titularidad pública están obligados, al cesar en sus funciones, a entregarlos al que les sustituya en las mismas o remitirlos al archivo que corresponda. No obstante, debe señalarse la mayor limitación del precepto de la Ley 7/2011, al referirse a personas que ejercen funciones el sector público, mientras que la LPHE impone el deber a cualquier persona por la función que desempeñen tengan a su cargo documentos de titularidad pública.
} 
Pero el precepto más novedoso en esta materia de la Ley 7/2011 es el que establece que el traspaso de funciones de algún órgano, ente u organismo público a otro conllevará la transferencia solo de los documentos producidos en el ejercicio de dichas funciones y que correspondan a procedimientos en tramitación o relativos a relaciones jurídicas vigentes que les afecten, sin perjuicio de aquellos que contengan información relevante para el funcionamiento de dicho órgano, ente u organismo -art. 13.1-. Del mismo modo, la Ley -art. 13.2- añade que la supresión o desaparición de algún órgano, ente u organismo público motivará la incorporación al órgano, ente u organismo que asuma sus funciones solo de los documentos a que se refiere el apartado anterior. Sin embargo, la Ley 7/2011 no contempla los supuestos de privatización de entes instrumentales del sector público. En tales casos, importa establecer que aunque la entidad de que se trate pierda la dependencia pública la documentación anterior al cambio de naturaleza o de dependencia mantiene la titularidad pública ${ }^{16}$.

\section{EL PATRIMONIO DOGUMENTAL DE ANDALUGÍA}

\section{Concepto de Patrimonio Documental de Andalucía}

La Ley 7/2011 -arts. 2.n) y 14- establece que «El Patrimonio Documental de Andalucía es el conjunto de los documentos producidos, recibidos o reunidos por las personas físicas o jurídicas, tanto públicas como privadas, ubicados en Andalucía, que poseen, por su origen, antigüedad o valor, interés para la Comunidad Autónoma» ${ }^{17}$. Dejando de lado el cambio de denominación (Patrimonio Documental de Andalucía en lugar de Patrimonio Documental Andaluz), en relación con la Ley 3/1984 destaca la exigencia de la ubicación de los documentos en Andalucía.

En efecto, la Ley 3/1984 establecía que el Patrimonio Documental Andaluz es parte integrante del Patrimonio Documental Español y está constituido por todos los documentos, reunidos o no en archivos, procedentes de un conjunto de instituciones y personas indicadas en la Ley (artículos $2^{\circ}, 3^{\circ}, 4^{\circ}$ y $5^{\circ}$ ), o fue-

\footnotetext{
${ }^{16}$ Así, Ley de Cataluña 10/2001 -art. 11-; Ley de la Comunidad Valenciana 3/2005 -art. 15.3-; Ley 15/2006 de Baleares -art. 15-.

${ }^{17}$ Por este motivo, la Ley 7/2011 modifica este precepto de la Ley 14/2007, que pasa a declarar que el Patrimonio Documental de Andalucía es el conjunto de los documentos producidos, recibidos o reunidos por las personas físicas o jurídicas, tanto públicas como privadas, ubicados en Andalucía, que poseen, por su origen, antigüedad o valor, interés para la Comunidad Autónoma en los términos establecidos en el presente capítulo - art. 69.1-.
} 
ren incluidos en el mismo, de acuerdo con lo previsto en la propia Ley (artículo $\left.6^{\circ}\right)$. Y la exigencia de ubicación del documento en la Comunidad Autónoma únicamente se establecía respecto a los documentos de titularidad privada de más de cien años -art. 5-, criterio seguido por la mayoría de las Comunidades Autónomas ${ }^{18}$.

Esta exigencia de ubicación parece tener origen, justamente, en la Ley 14/2007, de 26 de noviembre, de Patrimonio Histórico de Andalucía, que se declara de aplicación al Patrimonio Histórico Andaluz, el cual «se compone de todos los bienes de la cultura, materiales e inmateriales, en cuanto se encuentren en Andalucía y revelen un interés artístico, histórico, arqueológico, etnológico, documental, bibliográfico, científico o industrial para la Comunidad Autónoma» -art. 2-. Y, del mismo modo que forman parte del Patrimonio Histórico Andaluz los bienes muebles de relevancia cultural para Andalucía que se encuentren establemente en territorio andaluz -art. 42.1-19.

Ahora bien, la Ley 7/2011 no es del todo consecuente que esta exigencia conceptual, pues vuelve a exigir que se trate de documentos ubicados en la Comunidad Autónoma para los documentos de titularidad privada - art. 15.1.b) y c)-, pero no para los de titularidad pública. Por tanto, el concepto de Patrimonio Documental de Andalucía que expresa la Ley es, al menos, inexacto: debería decir «en su caso, ubicados en Andalucía», pues no trata de una exigencia conceptual.

Pero, incluso en relación con los documentos de titularidad privada la Ley presenta una nueva inconsistencia, cuando en su disposición adicional quinta (Retorno a la Comunidad Autónoma de documentos del Patrimonio Documental de Andalucía) ${ }^{20}$, establece: «La consejería realizará las gestiones oportunas conducentes al retorno a la Comunidad Autónoma de los documentos constitutivos del Patrimonio Documental de Andalucía que se encuentren fuera de Andalucía». En efecto, si se trata de documentos de titularidad privada que se encuentran

${ }^{18}$ Y, en tal sentido, la Ley 14/2007, de 26 de noviembre, de Patrimonio Histórico de Andalucía, en su versión original, declaraba que el patrimonio documental andaluz está constituido por todos los documentos de cualquier época, conservados, producidos o recibidos por las personas o instituciones de carácter público y privado, estén reunidos o no en los archivos de Andalucía, en los términos regulados en la legislación de archivos - art. 69.1-.

${ }^{19} \mathrm{Y}$ estos preceptos se completan con la disposición según la cual la Consejería competente en materia de patrimonio histórico «podrá realizar las gestiones oportunas conducentes al retorno a la Comunidad Autónoma de aquellos bienes que se consideren representativos de la cultura andaluza que se encuentren fuera del territorio de Andalucía»-disposición adicional primera- .

${ }^{20}$ Disposición evidentemente deudora de la disposición adicional primera de la Ley 14/2007. 
fuera de la Comunidad, en rigor, no pueden ser calificados de documentos «constitutivos del Patrimonio Documental de Andalucía», pues la ubicación en Andalucía es, según el artículo 15.1, requisito para que formen parte de dicho Patrimonio Documental de Andalucía.

\section{Documentos del Patrimonio Documental de Andalucía}

\section{A. Documentos de titularidad pública}

La Ley 7/2011 mantiene, en líneas generales, la estructura del Patrimonio Documental establecida en la Ley 3/1984 y adoptada por la LPHE -art. 49-, así como por la totalidad de las Comunidades Autónomas. De este modo, debe diferenciarse entre documentos de titularidad pública y privada.

Respecto a los primeros, la Ley 7/2011 -art. 15.1.a)- establece que forman parte del Patrimonio Documental de Andalucía los «documentos de titularidad pública de cualquier época, recogidos o no en archivos, definidos en el artículo 9, sin perjuicio de la normativa estatal e internacional que les sea de aplicación». Como ya la propia Ley 7/2011 -art. 9- ha definido -como nos constaqué se entiende por documentos de titularidad pública, nos remitimos a lo ya expresado más arriba. De este modo, y como no podía ser de otro modo, se mantiene el criterio de la Ley 3/1984 según el cual forman parte del Patrimonio Documental los documentos de titularidad pública «de cualquier época». Y no podía ser de otro modo, puesto que se trata de un criterio adoptado por la LPHE - art. 49.2-. Otra cosa es que tal vez sea necesario revisar el criterio del legislador básico ${ }^{21}$.

${ }^{21}$ Como he defendido en otro lugar (FERNÁNDEZ RAMOS, Severiano: "Legislación y Sistemas de Archivos de las Administraciones Públicas", en Los Sistemas de Archivos de las Comunidades Autónomas, Junta de Comunidades de Castilla- La Mancha, Consejería de Administraciones Públicas, Toledo, 2002, págs. 9-33), este criterio de no exigir antigüedad alguna a los documentos públicos para su integración en el Patrimonio Histórico es, sin duda, un criterio bien intencionado, movido por la voluntad de proteger preventivamente a dichos bienes. Sin embargo, tal vez no se han valorado suficientemente las consecuencias distorsionantes que conlleva, y si existen otras alternativas para conseguir los efectos pretendidos, sin forzar la necesaria coherencia de las instituciones integrantes del Patrimonio Histórico. En efecto, cabe dudar de la idoneidad de un criterio que supone integrar en el Patrimonio Histórico, de un modo indiscriminado, a todo documento que produce o reciben las personas y entidades del sector público, con independencia de su antigüedad y de su contenido y, en definitiva, si incorpora o no efectivamente un valor cultural. Criterio que aboca inevitablemente a contradicciones lógicas de difícil solución. Así, una de las directrices elementales del Patrimonio Histórico es la conservación de los bienes que lo integran, pero las propias normas que ordenan los documentos y archivos públicos han contemplado y ordenan, por necesidades imperiosas del sistema archivístico, la práctica de la eliminación de los documentos. Por esta razón, la Ley de Asturias 1/2001 sobre Patrimonio Cultural - art. 90.1- se ve obligada a realizar una pirueta jurídica. Así, 


\section{B. Documentos de titularidad privsada}

Respecto a los documentos de titularidad privada, la Ley 7/2011 mantiene, inicialmente, la triple distinción establecida en la Ley 3/1984 -arts. 4 a 6-, y recogida en la LPHE - art. 49.3 a 5-, a la que añade una cuarta categoría, a la cual va a conceder casi en exclusiva su atención.

- Documentos de más de cuarenta años de antigüedad en poder de entidades sociales.

La Ley 7/2011 -art. 15.1.b)- declara que forman parte del Patrimonio Documental de Andalucía «Los documentos ubicados en la Comunidad Autónoma con más de cuarenta años de antigüedad, conservados o no en archivos, producidos, recibidos o reunidos en el desarrollo de su actividad en Andalucía por las personas jurídicas privadas de carácter religioso, político, sindical, cultural, educativo o con fines sociales». Dejando de lado alguna imprecisión en la redacción de la Ley ${ }^{22}$, la Ley 3/1984 mantiene el plazo de los cuarenta años establecido en la LPHE - art. 49.3-. Por tanto, las principales novedades son dobles. De un lado, la exigencia - ya señalada- de que se trate de documentos ubicados en la Comunidad Autónoma, cuando lo cierto es que en la generalidad de las leyes autonómicas la exigencia de radicación en la Comunidad Autónoma está referida no a los documentos sino a la entidad titular de los mis$\operatorname{mos}^{23}$. De otro lado, aun cuando la Ley 7/2011 amplía el ámbito de la LPHE, al referirse a personas jurídicas privadas «con fines sociales», no obstante, delimita mejor el ámbito de esta categoría, el cual en la Ley 3/1984 era imposible de predeterminar ${ }^{24}$.

tras prohibir la destrucción de bienes que formen parte del Patrimonio Documental, se ve obligada a añadir: "Lo dispuesto en el apartado anterior no se aplicará en el caso de los bienes a que hacen referencia los artículos 80 y 81 (...) de esta Ley (esto es los documentos de entidades públicas), cuando se trate de labores de selección y expurgo habituales en la gestión de archivos". Si esto es así, cabe preguntarse si tiene verdaderamente sentido declarar solemnemente como bienes integrantes del Patrimonio Cultural a unos bienes que pueden destruirse con total normalidad, no como algo excepcional o patológico.

${ }^{22}$ En efecto, el precepto debería especificar que se refiere a entidades no incluidas en el apartado anterior, puesto que es perfectamente posible que existan personas jurídicas privadas de carácter cultural, educativo o con fines sociales, pertenecientes al sector público. De hecho, con mayor corrección, la LP$\mathrm{HE}$ - art. 49.3- se refiere a entidades, fundaciones y asociaciones culturales y educativas «de carácter privado».

${ }^{23}$ Por ello, cabe preguntarse si los documentos de estas entidades, aun cuando hayan sido generados en Andalucía, ¿al salir de la misma dejan de pertenecer al Patrimonio Documental de Andalucía, sin perjuicio, naturalmente, de su condición de Patrimonio Histórico Español?

24 A «Cualquier otro tipo de asociaciones y sociedades radicadas en Andalucía» se refería el artículo 4.d) de la Ley 3/1984. 


\section{- Documentos de más de 100 años de antigüedad en poder de cualquier persona.}

La Ley 7/2011 -art. 15.1.c)- declara que forman parte del Patrimonio Documental de Andalucía «Los documentos producidos, recibidos o reunidos por cualquier persona física o jurídica privada distinta de las señaladas en el apartado 1.b) (es decir, de las anteriores), ubicados en Andalucía, que a la entrada en vigor de esta ley tengan una antigüedad igual o superior a cien años». La exigencia de que los documentos se encuentren en la Andalucía, como se ha indicado, ya estaba contenida en la Ley 3/1984 - art. 5-, como también coincide el plazo de los cien años, recogido asimismo en la LPHE -art. 49.4-. De este modo, la novedad del precepto estriba en limitar la integración en el Patrimonio Documental de Andalucía a los documentos «que a la entrada en vigor de esta Ley tengan una antigüedad igual o superior a cien años» ${ }^{25}$.

El problema estriba en que la LPHE declara que integran asimismo el patrimonio documental los documentos con una antigüedad superior a los cien años generados, conservados o reunidos por cualesquiera otras entidades particulares o personas físicas -art. 49.4-. Podrá decirse que esta declaración no impide que los documentos que adquieran la antigüedad centenaria a partir de la entrada en vigor de la Ley 7/2011 sean integrantes del Patrimonio Histórico Español. Sin embargo, estimamos que se trata de una apreciación errónea: el legislador autonómico puede legítimamente, en ejercicio de sus competencias sobre patrimonio cultural, ampliar la protección a bienes más allá del Patrimonio Histórico Español. Pero lo que no puede hacer es limitar la extensión del Patrimonio Histórico Español, pues ello supone dejar huérfano a esa parte, ya que el Estado carece de competencias ejecutivas en materia patrimonio cultural, salvo en lo que atañe específicamente a la "defensa del patrimonio cultural, artístico y monumental español contra la exportación y la expoliación" - art. 149.1.28 CE-. En definitiva, consideramos que la limitación indicada a los documentos «que a la entrada en vigor de esta Ley tengan una antigüedad igual o superior a cien años» es anticonstitucional.

- Documentos incluidos en el Inventario de Bienes Reconocidos del Patrimonio Documental de Andalucía.

La Ley 7/2011 -art. 15.2- declara que también formarán parte del Patrimonio Documental de Andalucía aquellos documentos de naturaleza privada

\footnotetext{
${ }^{25}$ La Ley 3/1984 - art. 5- declaraba que forman, igualmente, parte del Patrimonio Documental andaluz «los documentos radicados en Andalucía, con una antigüedad superior a cien años, producidos o recibidos por cualesquiera otras entidades particulares o personas físicas», sin limitar la integración en el Patrimonio a una fecha determinada.
} 
que, sin alcanzar la antigüedad prevista en el apartado 1 (es decir, los 40 y 100 años reseñados), sean incluidos en el Inventario de Bienes Reconocidos del Patrimonio Documental de Andalucía previsto en la Ley -art. 16-, por poseer valores de interés para la Comunidad Autónoma. Lo cierto es que ya la Ley 3/1984 - art. 6- contempló la posibilidad de incluir en el Patrimonio Documental Andaluz a aquellos documentos o colecciones documentales (privadas) que, sin alcanzar la antigüedad antes señalada, merecieran dicha inclusión, cláusula que sería recogida también por la LPHE - art. 49.5-. Sin embargo, lo cierto es que tal procedimiento no llegó a regularse, ni al parecer llegó a aplicarse la posibilidad contemplada en la Ley.

De este modo, la principal novedad de la Ley 7/2011 consiste en crear el Inventario de Bienes Reconocidos del Patrimonio Documental de Andalucía -art. 16.1-, que se constituye como un instrumento que tiene por objeto facilitar la identificación de bienes integrantes de dicho Patrimonio, correspondiendo a la consejería su formación, actualización, coordinación y difusión ${ }^{26}$. Pues bien, en la creación de este Inventario de Bienes Reconocidos del Patrimonio Documental de Andalucía es evidente la influencia de la Ley 14/2007, de 26 de noviembre, del Patrimonio Histórico de Andalucía, que creó el Inventario de Bienes Reconocidos del Patrimonio Histórico Andaluz, justamente con idéntica finalidad de facilitar su identificación como integrantes de dicho Patrimonio, correspondiendo a la Consejería competente en materia de patrimonio histórico su formación, conservación y difusión -art. 13.1-27.

En cuanto al procedimiento para la inclusión en el Inventario de Bienes Reconocidos del Patrimonio Documental de Andalucía de los documentos, la Ley 7/2011 -art. 17- establece un procedimiento claramente inspirado en el de inscripción de bienes en el Catálogo General del Patrimonio Histórico Andaluz -art. 9 Ley 14/2007-28. El problema, a mi modo de ver, es que la figura de los documentos integrantes del Inventario de Bienes Reconocidos del Patrimonio Documental de Andalucía carece de relevancia en la ordenación del Patri-

\footnotetext{
${ }^{26}$ Según la Ley, formarán parte de este inventario los bienes a los que, en virtud de resolución de la dirección general competente en materia de documentos, archivos y patrimonio documental, se les reconozca como integrantes del Patrimonio Documental de Andalucía, conforme al procedimiento establecido en la propia Ley -art. 17-.

${ }^{27}$ No obstante, este Inventario de Bienes Reconocidos del Patrimonio Histórico Andaluz está pensado para bienes inmuebles y espacios vinculados a actividades de interés etnológico - art. 13.2 Ley 14/2007-.

${ }^{28}$ No especifica la Ley, como hubiera sido adecuado, la emisión de un informe preceptivo a cargo de la Comisión Andaluza de Patrimonio Documental y Bibliográfico - art. 98 Ley 14/2007 modificado por la propia Ley 7/2011-, en la que podría ser su principal función en relación con el patrimonio documental.
} 
monio Documental de Andalucía establecida en la propia Ley 7/2011, que finalmente utiliza a estos fines la figura jurídica a la que se hace seguidamente referencia.

\section{- Documentos inscritos en el Catálogo General del Patrimonio Histórico Andaluz.}

En efecto, la Ley 7/2011 -art. 15.3- establece que formarán parte del Patrimonio Documental de Andalucía cualesquiera documentos de valor relevante, contemplados o no en los categorías anteriores, que sean inscritos en el Catálogo General del Patrimonio Histórico Andaluz mediante cualquiera de las figuras de protección previstas en la Ley 14/2007, de 26 de noviembre, del Patrimonio Histórico de Andalucía (esto es, BIC, bienes de catalogación general y bienes incluidos en el Inventario General de Bienes Muebles del Patrimonio Histórico Español). Y al igual que sucede con el Inventario de Bienes Reconocidos del Patrimonio Histórico Andaluz -art. 13.2 Ley 14/2007-, la Ley 7/2011 -art. 16.3- establece que no formarán parte del Inventario de Bienes Reconocidos del Patrimonio Documental de Andalucía los bienes que se inscriban en el Catálogo General del Patrimonio Histórico Andaluz. Por tanto, pueden inscribirse en el Catálogo General tanto documentos pertenecientes a las dos primeras categorías, es decir con las antigüedad antes indicada, como documentos que carezcan de dicha antigüedad, y que podrían haberse incluido en el Inventario de Bienes Reconocidos del Patrimonio Documental de Andalucía 29 .

Pues bien, la posibilidad de declarar documentos como Bienes de Interés Cultural o como bienes de catalogación general, y su consiguiente inscripción en el Catálogo General del Patrimonio Histórico Andaluz, ya estaba implícita en la Ley 14/2007. De este modo, la Ley 7/2011 se limita a explicitar esta posibilidad y -como se verá- a anudarle un régimen jurídico específico. En todo caso, lo cierto es que es esta figura de documentos inscritos en el Catálogo General del Patrimonio Histórico Andaluz la que preside el régimen jurídico del Patrimonio Documental de Andalucía -arts. 20 a 24-, sin que la Ley 7/2011 haga uso alguno de la figura de los documentos incluidos en el Inventario de Bienes Reconocidos del Patrimonio Documental de Andalucía, que crea la propia Ley. Por ello, cabe preguntarse sobre la operatividad real de esta figura,

${ }^{29}$ La propia Ley 7/2011 declara incorporados al Catálogo General del Patrimonio Histórico Andaluz como bienes de interés cultural los documentos de conservación permanente custodiados en el Archivo General de Andalucía y en el archivo del Patronato de la Alhambra y Generalife, debiendo practicarse de oficio las inscripciones correspondientes - disposición adicional segunda-. 
con un procedimiento de inclusión casi tan largo y complejo como el de inscripción en el Catálogo General, pero sin las ventajas de que gozan los bienes inscritos en el mismo ${ }^{30}$.

\section{Régimen jurídico del Patrimonio Documental de Andalucía}

Aun cuando el Capítulo II lleva por epígrafe el Patrimonio Documental de Andalucía, en realidad, salvo los elementales deberes de integridad e información, el resto de los deberes que establece están referidos exclusivamente a los documentos de titularidad privada integrantes de dicho Patrimonio Documental. Más aún, como se verá seguidamente, la Ley 7/2011 casi únicamente se ocupa de proteger una categoría de documentos de titularidad privada integrantes de dicho Patrimonio Documental: los inscritos en el Catálogo General del Patrimonio Histórico Andaluz categoría que preside el régimen jurídico del Patrimonio Documental de Andalucía ${ }^{31}$.

\section{A. Integridad del Patrimonio Documental de Andalucía}

La Ley 7/2011 establece que no se podrá eliminar ningún documento constitutivo del Patrimonio Documental de Andalucía, salvo en los supuestos y mediante los procedimientos establecidos reglamentariamente -art. 18-. Se trata de un precepto casi idéntico al contenido en la Ley 3/1984, según el cual los documentos constitutivos del Patrimonio Documental andaluz no podrán ser eliminados, salvo en los supuestos y mediante los procedimientos que reglamentariamente se disponga -art. 19-32. De otro lado, la Ley 7/2011 sólo contempla consecuencias jurídicas para las acciones de eliminación de deter-

\footnotetext{
${ }^{30}$ Compárese el procedimiento de de inclusión en el Inventario de Bienes Reconocidos del Patrimonio Documental de Andalucía establecido en la Ley 7/2011 -art. 17- con el procedimiento de inscripción de bienes muebles de catalogación general establecido en la Ley 14/2007 - arts. 9-: el primero tiene una duración de 12 meses y el segundo de 18 meses, pero en el caso de solicitudes de inicio del procedimiento en el caso de Inventario de Bienes Reconocidos del Patrimonio Documental de Andalucía el plazo es de seis meses, mientras que en el caso del Catálogo es de tres meses.

31 Por ello no es exacta la afirmación de la exposición de motivos, según la cual se establecen «distintos regímenes jurídicos diferenciados para los documentos de titularidad pública, el Patrimonio Documental de Andalucía y los documentos y archivos inscritos en el Catálogo General del Patrimonio Histórico Andaluz, pudiendo con ello establecer la diversidad coherente de deberes y obligaciones y sus consecuentes infracciones y sanciones». Lo cierto es que el régimen de protección ordenado en la Ley es casi exclusivamente para la los documentos inscritos en el Catálogo General del Patrimonio Histórico Andaluz.

${ }^{32}$ No obstante, si bien estos procedimientos fueron objeto de ordenación para los archivos integrados en el Sistema Andaluz de Archivos, en relación con el patrimonio documental de titularidad privada no integrado en dicho sistema no llegaron a aprobarse los correspondientes procedimientos.
} 
minadas categorías de documentos integrantes del Patrimonio Documental de Andalucía ${ }^{33}$. De este modo, la eliminación, incluso intencionada, de documentos de titularidad privada integrantes del Patrimonio Documental de Andalucía, pero no catalogados o inventariados, será un hecho antijurídico carente de consecuencias jurídicas ${ }^{34}$.

\section{B. Deber de información}

La Ley 7/2011 establece que todas las personas físicas o jurídicas, con independencia de su régimen y naturaleza jurídica, que sean propietarias, titulares de derechos o poseedoras de documentos constitutivos del Patrimonio Documental de Andalucía, están obligadas a proporcionar la información que les sea requerida por la consejería en lo referente a tales documentos -art. 19-. Este es el principal deber en el que se plasma el amplísimo deber de colaboración de los particulares establecido en el artículo 6 de la Ley. Asimismo, se trata de un deber que no estaba lo suficientemente explicitado en la Ley 3/1984. Sin embargo, este deber de información es a requerimiento de la Administración. Sorprendentemente, la Ley no explicita el que debería ser el primer deber de los titulares de documentos privados integrantes del Patrimonio Documental, esto es el deber de comunicar su existencia a la Administración competente, y que es el presupuesto para que la Administración pueda hacer efectivo el resto de deberes establecidos en la Ley, incluido el de integridad del Patrimonio Documental antes reseñado ${ }^{35}$.

\section{Derechos de tanteo y retracto}

La Ley 7/2011 - art. 20- ordena los llamados derechos (en propiedad, potestades) de tanteo y retracto en caso de transmisión onerosa entre vivos de la

\footnotetext{
${ }^{33}$ La Ley 7/2011 tipifica como infracción muy grave la eliminación o todas aquellas actuaciones u omisiones que lleven aparejada pérdida, desaparición o daños irreparables en los documentos integrantes del Patrimonio Documental de Andalucía inscritos en el Catálogo General del Patrimonio Histórico Andaluz -art. 71.a)-, y como infracción grave la eliminación o todas aquellas actuaciones u omisiones que lleven aparejada pérdida, desaparición o daños irreparables en los documentos integrantes del Patrimonio Documental de Andalucía incluidos en el Inventario de Bienes Reconocidos del Patrimonio Documental de Andalucía -art. 72.a)-.

${ }^{34}$ Ciertamente el criterio de la Ley 3/1984 de calificar como infracciones muy graves las acciones y omisiones que lleven aparejadas la pérdida, destrucción, desaparición o que produzcan daño o perjuicio irreparable en el Patrimonio Documental Andaluz - art. 44-, era excesivo, pero al menos la Ley 7/2011 podía haber calificado como infracción leve la eliminación del documentos integrantes del Patrimonio Documental de Andalucía no catalogados o inventariados.

${ }^{35}$ Esta laguna ya fue puesta de manifiesto en nuestro trabajo, FERNÁNDEZ RAMOS, Severiano (2003): 247. Además, este deber está explicitado en algunas leyes autonómicas, como la Ley 15/2006 Baleares -art. 18.1-.
} 
propiedad o de los derechos sobre los documentos integrantes del Patrimonio Documental de Andalucía en términos similares a los ya establecidos en la Ley 3/1984 - art. 36-, si bien existen una diferencia relevante. En efecto, la Ley 7/2011 -art. 21.1.e)- limita el deber de notificación a los «documentos constitutivos del Patrimonio Documental de Andalucía inscritos en el Catálogo General del Patrimonio Histórico Andaluz». Puede convenirse que la generalización de estos derechos en la Ley 3/1984 era ciertamente excesiva ${ }^{36}$, pero esta limitación, además de innecesaria (pues los derechos de tanteo y retracto para los bienes inscritos en el Catálogo General del Patrimonio Histórico Andaluz ya están ordenados en la Ley 14/2007 -art. 17-), es excesivamente restrictiva, y no tiene parangón en el resto de la legislación autonómica. Estimamos que se podría haber aprovechado la creación del Inventario de Bienes Reconocidos del Patrimonio Documental de Andalucía para extender los derechos de tanteo y retracto a dichos documentos, pues el Inventario tiene por función justamente facilitar la identificación de los bienes integrantes de dicho patrimonio.

D. Otros deberes de los titulares y poseedores de documentos privados

La Ley 7/2011 estatuye en el artículo 21.1 una serie de deberes a las personas privadas, físicas o jurídicas, propietarias, titulares de derechos o poseedoras de documentos privados constitutivos del Patrimonio Documental de Andalucía. Sin embargo, la Ley 7/2011 precisa que los deberes que seguidamente se indican están referidos exclusivamente a los documentos «inscritos en el Catálogo General del Patrimonio Histórico Andaluz». Ciertamente es razonable modular los deberes legales deben en atención al grado de protección que merezcan los bienes, tal como hacen, con carácter general, la LPHE o la Ley 14/2007. No obstante, entiendo que tal vez la Ley 7/2011 se ha excedido en la contracción de algunos deberes, como seguidamente se indicará.

a) «Conservar organizados los documentos y custodiarlos». La Ley 3/1984 - art. 14.1- ya establecía un genérico deber de titulares de los documentos constitutivos del Patrimonio Documental andaluz a la «conservación y custodia de sus fondos documentales». Y lo cierto es que el deber de conservación y custodia es el deber esencial (no instrumental) de todo bien integrante del patrimonio histórico, con independencia de que sea objeto de

\footnotetext{
36 Debe recordarse que la LPHE limita los derechos de tanteo y retracto a los bienes declarados de interés cultural o incluidos en el Inventario general de bienes muebles - art. 38-.
} 
declaración específica o sea catalogado o inscrito en un registro, tal como establece la LPHE -art. 36.1-. Y, en tal sentido, debe recordarse que la Ley 14/2007 establece que las personas propietarias, titulares de derechos o simples poseedoras de bienes integrantes del Patrimonio Histórico Andaluz, se hallen o no catalogados, tienen el deber de conservarlos, mantenerlos y custodiarlos de manera que se garantice la salvaguarda de sus valores -art. 14.1-, precepto que habrá que entender de aplicación supletoria en materia de patrimonio documental -disposición final primera Ley 7/2011-. En definitiva, no se entiende por qué este deber tan elemental se restringe a los documentos catalogados. Pero, además, las normas autonómicas posteriores a la Ley 3/1984 han introducido deberes más precisos derivados del deber de conservar y organizar los documentos, y que la Ley 7/2011 ha omitido, como el deber inventariar describir los documentos.

b) «Facilitar la inspección de los documentos, y de los archivos en que estos se custodien, por parte de la consejería, que estará limitada por las normas que resulten de aplicación y, en particular, por el derecho a la intimidad y a la propia imagen». En realidad, esta obligación ya está ordenada en la Ley 14/2007 para todos los bienes y actividades inscritas en el Catálogo General del Patrimonio Histórico Andaluz - art. 14.2-. Pero, además, debe recordarse que la 14/2007 -art. 70.1- establece que las personas titulares o poseedoras de bienes integrantes del Patrimonio Documental Andaluz (sin exclusión) facilitarán la inspección de los mismos por parte de la Consejería competente en materia de patrimonio histórico ${ }^{37}$. Por ello, se trata de otra limitación injustificada.

c) «Permitir el acceso a los documentos, previa solicitud razonada, para su consulta, estudio o investigación, en los términos que regulan la presente ley y la legislación específica que le sea de aplicación. Para su cumplimiento, las personas titulares de los documentos podrán depositarlos en un archivo público del Sistema Archivístico de Andalucía, de acuerdo con los términos que se establezcan reglamentariamente». Como en el anterior caso, esta obligación ya está ordenada en la Ley 14/2007 para todos los bienes y actividades inscritas en el Catálogo General del Patrimonio Histórico Andaluz -art. 14.2-. Además, la propia Ley 7/2011 establece las reglas en materia de acceso a los documentos de titularidad privada inscritos en el Catálogo General del Patrimonio Histórico Andaluz - art. 66.2-. Pero sucede que la

37 Y con carácter aún más general así lo establece el artículo 23 de la Ley 14/2007 para todos los bienes integrantes del Patrimonio Histórico Andaluz. Además, el artículo 103.1 Ley 14/2007 declara que la potestad de inspección se ejercerá, asimismo, en materia de instituciones del Patrimonio Histórico, Patrimonio Documental y Bibliográfico. Y también el artículo 52.3 LPHE. 
LPHE - art. 52.4- establece este deber para todos los bienes constitutivos del patrimonio documental ${ }^{38}$. Por tanto, la ordenación de la Ley $7 / 2011$, además de innecesaria por estar ya contenida en la Ley 14/2007, es limitativa de la LPHE.

f) «Notificar a la consejería la transmisión a título de herencia, legado o donación de la propiedad, posesión o tenencia de los documentos en el plazo de tres meses, que se computará desde la fecha en que se haga efectiva la transmisión». Se trata de un deber que en la Ley 3/1984 presentaba un alcance general para todo el patrimonio documental.

g) «Comunicar a la consejería cualquier accidente o siniestro que motive la pérdida o destrucción de documentos dentro de las veinticuatro horas siguientes al suceso».

\section{E. Traslados de documentos de titularidad privada}

Debe recordarse que la Ley 3/1984, en su versión original, declaró que son de libre traslado, dentro del territorio nacional, pero sus propietarios o titulares habrán de comunicar previamente tales hechos a la Consejería de Cultura -art. 36.1-, regla ésta que es la más extendida en la legislación autonómica. Sin embargo, a raíz del conocido asunto del traslado fuera de la Comunidad del archivo privado de la fundación Casa Ducal de Medinaceli y de la insatisfactoria respuesta jurisdiccional al conflicto que suscitó ${ }^{39}$, la Ley $3 / 1984$ fue modificada por Ley 3/1999, en virtud de la cual se estableció un régimen de autorización previa de los traslados de todos los documentos integrantes del Patrimonio Documental Andaluz, con condiciones extraordinariamente restrictivas.

Por su parte, la Ley 7/2011 mantiene este régimen de autorización previa pero limitando sustancialmente su ámbito de aplicación. En efecto, mientras la Ley 3/1984 (tras la reforma efectuada por la Ley 3/1999) impuso el deber de autorización previa a todos los documentos de titularidad privada, la Ley 7/2011 refiere el deber a «los documentos de titularidad privada integrantes del Patrimonio Documental de Andalucía inscritos en el Catálogo General del

\footnotetext{
38 «La obligación de permitir el estudio por los investigadores podrá ser sustituida por la Administración competente, mediante el depósito temporal del bien en un archivo, biblioteca o centro análogo de carácter público que reúna las condiciones adecuadas para la seguridad de los bienes y su investigación».

${ }^{39}$ La sentencia de la Audiencia Nacional de 22-9-1999 (RJCA 1999\3641), excusándose en una circunstancia formal, denegó la existencia de la obligación de colaboración de la Administración del Estado, remitiéndose, además, el tribunal al art. 4.4 de la LRJPAC, tras la reforma operada por la Ley 4/1999, según el cual el contenido del deber de colaboración se desarrollará, en las relaciones entre la Administración General del Estado y la Administración de las Comunidades Autónomas, "a través de los instrumentos y procedimientos que de manera común y voluntaria establezcan tales Administraciones".
} 
Patrimonio Histórico Andaluz» - arts. 21.d) y 22.1-. Sin embargo, al igual que sucedía con los derechos de tanteo y retracto, si bien la extensión de estas figuras en la Ley 3/1984 era abiertamente excesiva ${ }^{40}$, de nuevo cabe preguntarse por qué no se extendió este deber a los documentos incluidos en el Inventario de Bienes Reconocidos del Patrimonio Documental de Andalucía. O, mejor aún, ¿por qué no disponer un deber, no ya de autorización, sino de comunicación previa para los traslados de los bienes inventariados? Con esto quiere señalarse que existen múltiples posibilidades de modular estos deberes, equilibrando las cargas a los titulares del patrimonio documental con las facultades de la Administración en orden a su protección.

Por lo demás, la única novedad destacable del régimen de los traslados establecido en la Ley 7/2011 consiste en limitar la noción misma de traslado, pues la Ley 3/1984 -art. 36.4- sujetó al deber de autorización los traslados incluso ¡dentro del mismo edificio! Por su parte, la Ley 7/2011 entiende por traslado el desplazamiento a otro inmueble, lo cual supone recuperar un criterio mínimo de razonabilidad ${ }^{41}$. Con todo, bien podría haberse limitado el deber de autorización a los traslados fuera de Andalucía y, en su caso, establecer un deber de comunicación previa para los traslados dentro de la Comunidad Autónoma.

\section{F. Depósito forzoso}

La Ley 3/1984 -art. 15.3- dispuso que cuando las deficiencias de instalación pongan en peligro la conservación y seguridad de los documentos constitutivos del Patrimonio Documental andaluz existentes en Archivos se dispondrá por la Consejería de Cultura las medidas de garantía necesarias y se podrá decidir su depósito en otros archivos, hasta tanto desaparezcan los motivos de aquel peligro. Por tanto, el depósito se podía ordenar para conservar cualquier documento constitutivo del Patrimonio Documental andaluz. Por el contrario, la Ley 7/2011 -art. 23.1- establece que cuando no se reúnan las condiciones necesarias para garantizar la conservación, seguridad o acceso de los documentos constitutivos del Patrimonio Documental de Andalucía «inscritos en el Catálogo General del Patrimonio Histórico Andaluz», la consejería requerirá

${ }^{40}$ En nuestro trabajo FERNÁNDEZ RAMOS, Severiano (2003): 250, ya dudamos de la efectividad de la Ley, preguntándonos hasta qué punto dispone la Administración autonómica de capacidad real para controlar el ingente movimiento de documentos que cotidianamente tiene lugar. Por su parte, el anteproyecto de ley mantenía idéntica extensión para todo traslado de los documentos de titularidad privada integrantes del patrimonio documental de Andalucía.

${ }^{41}$ En este sentido, la Ley 14/2007 exceptúa de la obligación de comunicación previa de traslados de 
a las personas propietarias, titulares de derechos o poseedoras de los mismos la adopción de medidas necesarias para subsanar la situación.

Lo cierto es que si se restringe esta medida a los documentos inscritos en el Catálogo General del Patrimonio Histórico Andaluz, debe recordarse que ya la Ley 14/2007 establece, con carácter general, que la Consejería competente en materia de patrimonio histórico podrá ordenar a las personas propietarias, titulares de derechos o simples poseedoras de bienes inscritos en el Catálogo General del Patrimonio Histórico la adopción de las actuaciones necesarias para su conservación, mantenimiento y custodia -art. 15.1-. Más aún, teniendo presente que el deber de conservación es un deber común a todos los bienes históricos, no se entiende bien por qué limitar el depósito forzoso a los documentos inscritos en el Catálogo General del Patrimonio Histórico Andaluz ${ }^{42}$.

\section{G. Expropiación forzosa y medidas de fomento}

La Ley 7/2011 -art. 24.1- establece que la falta de cumplimiento de las obligaciones establecidas en la ley para las personas físicas y jurídicas privadas propietarias, titulares de derechos o poseedoras de documentos constitutivos del Patrimonio Documental de Andalucía inscritos en el Catálogo General del Patrimonio Histórico Andaluz facultará a la Administración autonómica para la expropiación total o parcial de los mismos por causa de interés social, con objeto de garantizar su conservación. De nuevo, la principal novedad consiste en constreñir la potestad expropiatoria, prevista por la Ley 3/1984 para todo el patrimonio documental - art. 36.9- a los documentos inscritos en el Catálogo General del Patrimonio Histórico Andaluz, cuando lo cierto es que para este tipo de bienes ya viene prevista la expropiación forzosa en la Ley 14/2007 - art. 18-43.

\footnotetext{
bienes muebles el cambio de ubicación dentro del mismo inmueble en el que esté el bien -art. 45.1-. En nuestro trabajo FERNÁNDEZ RAMOS, Severiano (2003): 250, estimamos que el riguroso régimen establecido en esta Ley, que no se olvide tiene su origen en un suceso singular, suscita serias dudas tanto de constitucionalidad, por constituir una limitación excesiva y desproporcionada del derecho de propiedad y de la libertad de circulación de bienes.

${ }^{42}$ Con todo, debe entenderse aplicable el artículo 52.2 LPHE, según el cual si los sujetos obligados incumplen el deber de conservar y, proteger los documentos, la Administración competente adoptará las medidas de ejecución oportunas, conforme a lo previsto en el artículo 36.3 de la propia Ley.

${ }^{4}$ Según la Ley 14/2007, la falta de cumplimiento de las obligaciones establecidas en la Ley para las personas propietarias, poseedoras o titulares de derechos sobre bienes inscritos en el Catálogo General del
} 


\section{EL SISTEMA ARCHIVÍSTICO DE ANDALUCÍA}

\section{Conceptos}

La Ley 3/1984 presentó - como se ha indicado antes- la innovación de pretender introducir la idea de Sistema en el ámbito legal de los archivos. Ahora bien, la Ley no definía el Sistema Andaluz de Archivos más allá de su configuración como una red de centros integrado por órganos y archivos -art. 9 y 12-44. Por su parte, dejando de lado el cambio terminológico ${ }^{45}$, la Ley 7/2011 -arts. 2.l) y 26- define el Sistema Archivístico de Andalucía como el conjunto de órganos, archivos y centros que llevan a cabo la planificación, dirección, coordinación, ejecución, seguimiento e inspección de la gestión de los documentos integrantes del Patrimonio Documental de Andalucía y de los archivos integrados en dicho Sistema Archivístico, de acuerdo con lo previsto en el artículo 40 (precepto que clasifica los archivos que integran el Sistema Archivístico de Andalucía se clasifican en razón de su titularidad y gestión), sin perjuicio de lo establecido en la legislación estatal que le sea de aplicación. Ahora bien, la definición de sistema de archivos de la Ley 7/2011 puede ser controvertida, pues hace coincidir su objeto con el Patrimonio Documental, cuando lo cierto es que la propia Ley 7/2011 reconoce que la pertenencia al Patrimonio Documental es independiente de que los documentos estén recogidos o no en archivos - art. 15.1.a)-, por muy amplio que sea la noción de archivo que se maneje. De este modo, seguirá siendo necesario el ejercicio de unas funciones públicas orientadas a la conservación, protección y difusión del Patrimonio Documental al margen del Sistema Archivístico.

De otro lado, la Ley 7/2011 -arts. 2.d) y 33.1- recoge la definición de archivo más extendida, al entender por archivo «el conjunto orgánico de docu-

Patrimonio Histórico facultará a la Administración para la expropiación total o parcial del bien por causa de interés social - art. 18.1-. Además, tampoco puede olvidarse que la LPHE -art. 52.2- establece que el incumplimiento de las obligaciones por parte de los poseedores de bienes del patrimonio documental (sin exclusión), cuando además sea desatendido el requerimiento por la Administración, podrá ser causa de interés social para la expropiación forzosa de los bienes afectados.

${ }^{44}$ El Decreto 97/2000, de 6 marzo, del Sistema Andaluz de Archivos, dio un paso más al declarar que el Sistema Andaluz de Archivos se configura como una red de centros formada por un conjunto de órganos y archivos que se integran, a su vez, por razón de su titularidad y gestión en subsistemas y redes -art. 4-.

45 De «Sistema Andaluz de Archivos» (expresión de la Ley 3/1894 y del Decreto 97/2000, de 6 marzo) se pasa a «Sistema Archivístico de Andalucía» - disposición adicional $7^{\text {a }}$-, en un estilo generalizado en la legislación andaluza, así como en otras Comunidades Autónomas. 
mentos producidos o recibidos en el ejercicio de sus funciones por las personas físicas o jurídicas, públicas y privadas. Se entiende también por archivo, a efectos de la presente ley, aquella unidad administrativa o institución que custodia, conserva, organiza y difunde los documentos, incluidos los electrónicos, en cualquier etapa de su producción o tratamiento, para la gestión administrativa, la información, la investigación y la cultura» ${ }^{46}$. De este modo, al margen de la mención a los documentos electrónicos (un tanto innecesaria dada la amplitud de la noción de documento), la principal novedad consiste añadir a la noción de institución, la unidad administrativa, de forma que quedan englobados tanto los archivos históricos (instituciones) como los administrativos (unidades administrativas $)^{47}$.

También contiene la Ley 7/2011 - arts. 2.e).f), 34.1 y 35- nociones sobre archivos públicos y privados, si bien esta distinción carece de relevancia efectiva, pues de manera similar a lo que sucedía en la Ley 3/1984, en la cual la distinción con relevancia legal era la que existía entre archivos de uso público y los privados que no fuesen de uso público, en la Ley 7/2011 la distinción con relevancia legal es la de archivos integrados o no en el Sistema Archivístico -arts. $36,37.2,39-{ }^{48}$.

De otro lado, la Ley 7/2011 -art. 33.3- admite que podrán constituirse redes de archivos en razón del traspaso de la custodia de los documentos a lo largo de la vida de estos. Asimismo, se podrán establecer otros tipos de redes de archivos dis-

${ }^{46}$ La Ley 3/1984 - art. 1.3-, en su versión original, entendió por archivo «el conjunto orgánico de los documentos conservados total o parcialmente con fines de gestión, defensa de los derechos información, investigación y cultura». De este modo, la Ley identificaba el archivo con la noción de fondo documental. Pero la reforma de la Ley 3/1984 operada por la Ley 1/1991, de 3 de julio, añadió a la noción de la Ley 3/1984 que reciben «también el nombre de Archivos las instituciones donde se conservan, ordenan o difunden conjuntos orgánicos de documentos», incorporando la dualidad conceptual introducida por la LPHE - art. 59.1-.

47 Así, la propia Ley 7/2011 -art. 43.1- define a los archivos centrales como unidades administrativas.

${ }^{48}$ Incluso en relación con el derecho de acceso, donde cabe esperar mayor diferencia de régimen entre archivos públicos y privados, la Ley 7/2011 - art. 66.1- establece que el acceso a los documentos de titularidad privada que formen parte del Patrimonio Documental de Andalucía y que se encuentren en archivos privados integrados en el Sistema Archivístico de Andalucía se regirá por las normas de acceso a los documentos de titularidad pública, de modo que la diversidad de régimen se declara para los archivos privados no integrados en el Sistema Archivístico - art. 66.2-. Únicamente cabe reseñar, en sede del régimen sancionador, el artículo 74.2, según el cual las personas titulares de los archivos privados serán responsables solidarios de las infracciones cometidas por su personal o por otras personas vinculadas a aquellos por cualquier otro título.

Revista Andaluza de Administración Pública

ISSN: 0034-7639, núm. 82, Sevilla, enero-abril (2012), págs. 13-72 
tintas a las mencionadas en el apartado anterior con objeto de compartir y explotar información. Así, la Ley -art. 2.k)- define las redes de archivos como el conjunto de archivos vinculados entre sí en razón del traspaso de la custodia de los documentos a lo largo de la vida de estos o de la posibilidad de compartir y explotar información común o de poseer características comunes. No se molesta la Ley, en cambio, en definir qué se entiende por el ciclo vital de los documentos, a diferencia de otras leyes autonómicas. Parece que se ha querido intencionadamente evitar toda referencia a las fases o edades de la documentación, cuando lo cierto es que se trata de conceptos estrechamente vinculados ${ }^{49}$.

Por lo demás, la Ley 7/2011 ordena de modo más o menos completo la red de archivos de archivos de la Junta de Andalucía - arts. 41 y ss.-, contemplando las categorías más extendidas de archivos en función de la cadena de custodia: archivos de oficina, centrales, intermedios (los archivos provinciales intermedios y el Archivo General de Andalucía) y archivos históricos (los archivos históricos provinciales, el Archivo de la Real Chancillería de Granada y el Archivo General de Andalucía). Ahora bien, en relación con los archivos de las entidades locales de Andalucía y de las universidades públicas de Andalucía, en razón a su autonomía, la Ley se limita a establecer que cada entidad local y cada universidad pública «establecerá» su propia red de archivos, que incluirá los de sus entidades instrumentales -arts. 49.2 y $50-$.

\section{2. Órganos del Sistema Archivístico de Andalucía}

\section{A. Los órganos ejecutivos}

- Consejo de Gobierno. Siguiendo casi al pie de la letra la Ley 14/2007 -art. 92-, la Ley 7/2011 -art. 28- establece que, bajo la superior dirección del Consejo de Gobierno se ejercerá el conjunto de competencias en materia de documentos, archivos y patrimonio documental previstas en la presente ley, conforme al reparto de funciones que se dispone en los preceptos siguientes. Por tanto, en realidad, no se asigna función ejecutiva alguna al Consejo de Gobierno.

\footnotetext{
${ }^{49}$ Como señala la Ley Foral de Navarra 12/2007 - art. 2.g)-, el ciclo vital de los documentos es la secuencia de fases en las que se estructura la vida del documento, desde su creación hasta su conservación definitiva, en consideración a su importancia como testimonio histórico, o bien hasta su eliminación una vez agotado su valor administrativo. De este modo, a partir de la Ley de Cataluña 10/2001 -art. 2-, el resto de las Leyes autonómicas diferencian tres edades de los documentos que se corresponden con las fases activa, semiactiva e inactiva o histórica: Ley de la Comunidad Valenciana 3/2005 -art. 3-; Ley de Baleares 15/2006 -art. 2-; Ley de Extremadura 2/2007 -art. 46.2-; Ley Foral de Navarra 12/2007 -art. $15.2-$.
} 
-Consejería competente. De nuevo siguiendo de cerca la Ley 14/2007 - art. 93-, la Ley 7/2011 -art. 29.1- establece que la consejería competente en materia de documentos, archivos y patrimonio documental será responsable de la formulación y ejecución de la política dirigida a la tutela, enriquecimiento y difusión del Patrimonio Documental de Andalucía, así como la dirección y coordinación del Sistema Archivístico de Andalucía. Sobre esta determinación conviene mencionar dos aspectos. De un lado, a diferencia de la Ley 3/1984, ya no se menciona nominativamente a la Consejería de Cultura, sino que con mejor técnica legislativa la referencia se realiza a la consejería competente en materia de documentos, archivos y patrimonio documental ${ }^{50}$. Esta técnica es más respetuosa con la competencia del Presidente de la Junta de Andalucía para distribuir las competencias entre las Consejerías (art. 10 de la Ley 6/2006, de 24 de octubre, del Gobierno). De otro lado, la Ley procura no introducir injerencias en el ámbito competencial de otras consejerías, apelando a la cooperación y coordinación en particular con las consejerías competentes en materia de política informática y de administración electrónica - arts. 27.3, 29.1, 58.2-, así como en materia de Administración de Justicia - arts. 29.2.e) y 60.5-. Prevenciones que llevan a plantear, una vez más, la conveniencia de una revisión de la tradicional adscripción orgánica al departamento competente en materia de cultura, reforzada por el ahora reconocido por la Ley carácter trasversal de la gestión documental ${ }^{51}$. Además, aun cuando no se mencione en capítulo dedicado a los órganos, la Ley 7/2011 asigna expresamente diversas funciones ejecutivas a la dirección general competente en materia de documentos, archivos y patrimonio documental -arts. 16.2, 17.4, 23.3, 78.1.b)-, determinaciones que no implican que exista una dirección general con competencias «exclusivas» en esta materia ${ }^{52}$.

\footnotetext{
${ }^{50}$ Lo que no se entiende bien es que en casi todos los preceptos [16.1, 17.1, 19, 46.2, 20.2, 20.3, 20.4, $20.5,21.1,21.2,22.1,22.6,22.7,23.1,23.2,23.3,24.3,30,36.1 . c), 37.1,39.2,46.2,47.2,52.1$ y $5,55.2$, $59,60.2,63.1,66.2 . c), 67.1,76.2$, disposiciones adicionales $3^{\mathrm{a}}$ y $\left.5^{\mathrm{a}}\right]$ se omita esta referencia competencial, mencionando exclusivamente «la consejería», sobre todo cuando en ningún momento de explicita que por tal consejería debe entenderse la competente en materia de documentos, archivos y patrimonio documental. Además, si bien en la mayoría se escribe con minúscula, en algunos preceptos sigue apareciendo con mayúsculas (47.2 y 60.2). No cierto es que en el Proyecto de Ley presentado en el Parlamento -art. 5- sí se advertía del uso abreviado del término «consejería», pero esta advertencia se suprimió tras el dictamen de la Comisión.

${ }^{51}$ En otro lugar ya nos pronunciamos sobre la conveniencia de adscribir la competencia en materia de archivos a un Departamento con competencias no sectoriales sino horizontales o transversales, como Presidencia o Administraciones Públicas, FERNÁNDEZ RAMOS, Severiano (2003): 254.

${ }^{52}$ En mi opinión, se trata de un grado de determinación orgánica impropio de una ley. En no pocas
} 
-Delegaciones provinciales. Siguiendo de nuevo casi al pie de la letra la Ley 14/2007 -art. 94-, la Ley 7/2011 declara que corresponderá a las delegaciones provinciales de la consejería el ejercicio de las funciones ejecutivas que se establezcan reglamentariamente, así como las que les delegue la consejería -art. 30-, precepto evidentemente superfluo ${ }^{53}$.

\section{B. Comisión Andaluza de Valoración y Acceso a los Documentos}

La Ley 7/2011 -art. 31.1-incluye a la Comisión Andaluza de Valoración y Acceso a los Documentos dentro de los órganos ejecutivos, y la define como el órgano colegiado de carácter técnico y de participación, al que corresponde la valoración de los documentos de titularidad pública y la aplicación de su régimen de acceso. Este órgano viene a sustituir a la anterior Comisión Andaluza Calificadora de Documentos Administrativos ${ }^{54}$. De este modo, la Ley 7/2011 sigue el ejemplo de otras Leyes autonómicas de ampliar las competencias de las tradicionales comisiones de calificación o valoración atribuyéndoles funciones en materia de acceso a los documentos, en consonancia con la mayor relevancia que se asigna a esta cuestión en el Sistema.

Así, entre las funciones de la Comisión Andaluza de Valoración y Acceso a los Documentos destaca la de evacuar «informe preceptivo en los recursos o reclamaciones presentados contra las denegaciones del derecho de acceso a los documentos custodiados en los archivos del Sistema» - art. 31.3- . Debe señalarse la amplitud de esta función, pues alcanza a archivos no sólo de la Junta de Andalucía sino a todos los integrados en el Sistema, tanto públicos como privados. En relación con los archivos de las entidades locales, la previsión de un informe preceptivo a cargo de un órganos «ejecutivo» de la Administración de la Junta de Andalucía, no se compagina bien con la supresión de controles autonómicos impulsada por la Ley 5/2010, de 11 de junio, de Autonomía Local de Andalucía ${ }^{55}$. Además, se asigna a esta Comisión también la función de

\footnotetext{
leyes, las competencias ejecutivas se refieren de forma genérica a la Administración de la Junta de Andalucía, sin condicionar así decisiones organizativas futuras.

${ }^{53}$ La única competencia que asigna la Ley 7/2011 a las delegaciones provinciales de la consejería competente en la materia es la sancionadora - art. 78.1.a)-.

${ }^{54}$ Así la disposición adicional $7^{\text {a }}$ dispone que la Comisión Andaluza Calificadora de Documentos Administrativos, creada por el Decreto 97/2000, de 6 de marzo, pasa a denominarse «Comisión Andaluza de Valoración y Acceso a los Documentos».

55 Tal vez habría sido más respetuoso con la autonomía local contemplar la posibilidad de que las entidades locales puedan crear comisiones similares, y sólo en ausencia de éstas entraría en juego la Comisión Andaluza de Valoración y Acceso a los Documentos.
} 
unificar los criterios de aplicación de la legislación vigente en materia de acceso a los documentos de titularidad pública y a su información ${ }^{56}$. Por lo demás, la Ley 7/2011 -art. 31.2- remite por completo la determinación de la composición de la Comisión al desarrollo reglamentario, si bien debe subrayarse que la propia Ley califica a este órgano como de carácter técnico ${ }^{57}$.

\section{Comisión del Sistema Archivístico de Andalucía}

La Ley 7/2011 -art. 32.1- define la Comisión del Sistema Archivístico de Andalucía como el órgano colegiado, consultivo y de participación de la Administración de la Junta de Andalucía, en las materias relacionadas con el Sistema Archivístico de Andalucía. Este órgano viene a sustituir a la anterior Comisión de Coordinación del Sistema Andaluz de Archivos, regulada en el Decreto 97/2000, de 6 de marzo - disposición adicional $7^{\mathrm{a}}$ - . Asimismo, la Ley 7/2011 - art. 32.2- remite por completo la composición de la Comisión al desarrollo reglamentario, si bien, declara que, con el fin de posibilitar el eficaz desarrollo de la colaboración con las personas titulares de los archivos integrados en el Sistema, se asegurará la representación adecuada de todos ellos en los órganos ejecutivos, consultivos o de cualquier otro tipo que se creen en el marco de la presente Ley -art. 5.4-. Con todo, el principal problema que plantea este órgano es que sus funciones son marcadamente desdibujadas, lo que lleva a pensar que no tendrá mejor suerte que la anterior Comisión de Coordinación del Sistema Andaluz de Archivos ${ }^{58}$.

\section{Régimen de los archivos del Sistema Archivístico de Andalucía}

Siguiendo el criterio más extendido en la legislación autonómica, la Ley 7/2011 establece un régimen común para todos los archivos integrados en el

\footnotetext{
56 Así la Ley 7/2011 establece que la Comisión Andaluza de Valoración y Acceso a los Documentos podrá establecer criterios homogéneos sobre la aplicación de la normativa de acceso, pudiendo dar publicidad a sus informes - art. 62.6-

${ }^{57}$ En este sentido, en otro lugar defendí que la comisión debía tener un perfil técnico, y en su composición no debería buscarse tanto la adecuada representación de los distintos agentes que integran el sistema de archivos como su cualificación técnica - principalmente en el ámbito de la archivística y del Derecho-. FERNÁNDEZ RAMOS, Severiano (2003): 255.

${ }^{58}$ La Ley -art. 32.3- atribuye a la Comisión del Sistema Archivístico de Andalucía las funciones siguientes: a) Actuar como órgano de información, consulta y asesoramiento del Sistema Archivístico de Andalucía. b) Elevar propuestas sobre cualquier otra medida para el mejor cumplimiento de los fines del Sistema Archivístico de Andalucía. c) Conocer e informar los planes que se refieran al Sistema Archivístico de Andalucía. d) Cualesquiera otras funciones que se determinen reglamentariamente. De este modo, apenas
} 
Sistema Archivístico de Andalucía, con independencia de su titularidad - art. 36-, y que no presentan gran novedad (deberes de organizar, conservar, custodiar y servir los documentos de sus archivos, de velar por el cumplimiento de los requisitos técnicos que se establezcan, entre otros).

Entre estos deberes destacan los referentes al personal de los archivos. Ya la Ley 3/1984 dispuso que los Archivos de uso público estarán atendidos por personal suficiente y con la cualificación y el nivel que exijan las diversas funciones, de acuerdo con la reglamentación que se establezca -art. 32-, reglamentación que nunca ha llegado de aprobarse ${ }^{59}$. Por su parte, las determinaciones de la Ley 7/2011 en este punto son claramente decepcionantes, pues se limita a -art. 39.1- prever que «Reglamentariamente se establecerán la cualificación y el nivel técnico necesarios del personal técnico con funciones archivísticas que preste servicio en los archivos del Sistema Archivístico de Andalucía para la gestión, la protección, el acceso y el servicio de los documentos de titularidad pública y del Patrimonio Documental de Andalucía».

La Ley 7/2011 -art. 39.1- establece que reglamentariamente se establecerán las condiciones sobre infraestructuras, instalaciones y equipamientos necesarios para la seguridad y la conservación de los documentos custodiados en dichos archivos, todo ello sin perjuicio de las normas que dicte el Estado en el ejercicio de sus competencias. La Consejería facilitará recomendaciones técnicas para la construcción, reforma o adaptación de los edificios en los que se ubiquen documentos de titularidad pública. Además, reproduciendo un precepto ya contenido en la Ley 3/1984 - art. 20.2- y en la LPHE - art. 64-, la Ley 7/2011 - art. 39.3- declara de utilidad pública a los efectos de expropiación forzosa los edificios y terrenos en los que vayan a ser instaladas dependencias de archivos de titularidad de la Junta de Andalucía ${ }^{60}$. Sin embargo, se echa en fal-

se avanza algo más en las competencias en relación con la anterior Comisión de Coordinación del Sistema Andaluz de Archivos. Ni siquiera se reconoce la típica competencia a esta clase de órganos participativos de informar preceptivamente las disposiciones generales de desarrollo del Sistema Archivístico, pues la Ley únicamente habla de informar los planes, a los que, por cierto, la Ley apenas concede atención.

59 Así, el diagnóstico de la situación que reconoce la propia Administración autonómica en el Plan Estratégico de Cultura de Andalucía (PECA 2007-2011) es el siguiente: «No siempre se encuentra personal especializado al frente de los archivos, situación que generaliza en el ámbito de la administración local, no así en el de la administración de la Junta de Andalucía. (...) Pese a la existencia de disposiciones reglamentarias, la realidad nos hace palpable la carencia sustancial de personal en los archivos de titularidad y/o gestión autonómica».

${ }^{60}$ Lo cierto es que la LPHE - art. 64- va más allá, al añadir que esta declaración de utilidad pública se extenderá a los edificios y terrenos contiguos a los archivos cuando así lo requieran razones de seguridad o sea necesaria para la adecuada conservación de los inmuebles o de los bienes que contengan. En este sentido, Ley de la Comunidad Valenciana 3/2005 - art. 22-. 
ta un precepto según el cual en la construcción o reforma de cualquier edificio como sede administrativa de un organismo público debía preverse el espacio necesario y adecuado para la instalación del archivo correspondiente.

Asimismo, la Ley - art. 34.2- establece que los inmuebles de titularidad de la Comunidad Autónoma destinados a la instalación de archivos para la conservación definitiva de documentos integrantes del Patrimonio Documental de Andalucía tendrán la protección que la Ley 14/2007, de 26 de noviembre, del Patrimonio Histórico de Andalucía, establece para los bienes de interés cultural, de acuerdo con lo dispuesto en su artículo $75^{61}$.

En lo que se refiere a los derechos de las personas titulares de los archivos del Sistema Archivístico de Andalucía, únicamente puede mencionarse el precepto - art. 37.2- según el cual los criterios de valoración que se establezcan en las bases reguladoras de las subvenciones y ayudas que conceda la Junta de Andalucía para el apoyo técnico y económico a los archivos primarán que se trate de archivos integrados en el Sistema Archivístico de Andalucía. Es decir, ni siquiera se exige la integración en el Sistema como presupuesto para poder recibir subvenciones, pues, de hecho, la Ley permite expresamente a la consejería establecer medidas de fomento y de apoyo técnico y económico, a las que podrán acceder las personas titulares de los archivos ubicados en Andalucía -art. 37.1-. De este modo, puede señalarse que la Ley 7/2011 no acierta a reflejar las ventajas de una integración voluntaria en el Sistema por parte de los archivos privados ${ }^{62}$.

Finalmente, la Ley 3/1984 no pudo prever la importancia práctica que, por motivos que sería largo detallar ahora, ha adquirido el fenómeno de la exter-

${ }^{61}$ Lo cierto es que el artículo 75.3 de la Ley 14/2007 establece que gozarán de la protección que la presente ley establece para los bienes de interés cultural los inmuebles de titularidad de la comunidad autónoma destinados a la instalación de archivos (bibliotecas, centros de documentación, museos y espacios culturales, así como los bienes muebles integrantes del patrimonio histórico andaluz en ellos custodiados). Es decir, la Ley 14/2007 no limita esta declaración a los archivos históricos, como sí hace la Ley 7/2011. Por lo demás, debe recordarse que la LPHE - art. 60.1- estableció que quedarán sometidos al régimen que la presente Ley establece para los bienes de interés cultural los inmuebles destinados a la instalación de archivos (bibliotecas y museos) de titularidad estatal, así como los bienes muebles integrantes del Patrimonio Histórico Español en ellos custodiados.

62 Así, otras leyes autonómicas (Ley de Extremadura 2/2007 - art. 51-; Ley Foral 12/2007 de Navarra -art. 11-) prevén determinados beneficios para los archivos integrados en el correspondiente Sistema Archivístico, como son el asesoramiento científico y técnico que presten los órganos del Sistema; la participación en programas de formación y mejora de la cualificación profesional del personal del archivo; o la colaboración económica para la mejora y funcionamiento de los archivos. 
nalización de los servicios de archivo en las Administraciones públicas españolas ${ }^{63}$. Sin embargo, algunas Leyes autonómicas de segunda generación sí han contemplado estas prácticas estableciendo algunas cautelas razonables ${ }^{64}$. Por el contrario, la Ley 7/2011 omite toda referencia a tan extendida práctica, y no parece que ignorar una realidad tan notoria sea la mejor política para afrontarla.

\section{Archivos de la Junta de Andalucía}

\section{A. Clasificación de los archivos}

La Ley 7/2011 -art. 40- establece que los archivos que integran el Sistema Archivístico de Andalucía se clasifican en razón de su titularidad y gestión en:

a) Archivos de la Junta de Andalucía. Aquí se incluyen tanto los archivos de titularidad y gestión de la Junta de Andalucía, como los archivos de titularidad estatal y gestión de la Junta de Andalucía -art. 41-. En nuestra opinión, es al menos confuso denominar a estos últimos «archivos de la Junta de Andalucía» - art. 41-, pues parecería que son de titularidad autonómica. Habría sido más correcto declarar que estos archivos de titularidad estatal y gestión de la Junta de Andalucía forman parte del subsistema archivístico de la Junta de Andalucía, tal como hacen otras leyes autonómicas ${ }^{65}$. De otro lado, no está clara la aplicación de la Ley a los archivos sanitarios, pues aunque no están expresamente excluidos, la disposición adicional décima parece cumplir esa función de modo tácito ${ }^{66}$.

\footnotetext{
${ }^{63}$ Las causas de este fenómeno obedecen principalmente a las circunstancias crónicas de falta de medios personales - cualificados y auxiliares-y materiales de todo tipo, agravada por ingente acumulación de documentos producida desde Véase Vid. A. TORREBLANCA LÓPEZ, "Externalización y privatización en los archivos de la Administración General del Estado", y S. FERNÁNDEZ RAMOS, "La privatización de la gestión de los archivos públicos: aspectos legales", ambos en Boletín ANABAD, LI, 2001.

${ }^{64}$ Ley de Cataluña 10/2001 de Archivos y Documentos - art. 8-; Ley de Castilla La Mancha 19/2002 de Archivos Públicos - art. 9-; Ley de la Comunidad Valenciana 3/2005, de 15 de junio, de Archivos -art. 20.1-; Ley 15/2006, del 17 de octubre, de archivos y patrimonio documental de las Illes Balears -art. 12-; Ley Foral 12/2007, de 4 de abril, de Archivos y Documentos.

${ }^{65}$ Por ejemplo, Ley 15/2006, del 17 de octubre, de archivos y patrimonio documental de las Illes Balears -art. 33- $^{-}$

${ }^{66}$ La disposición declara que en los centros del sistema sanitario público de Andalucía existirá un archivo, que contendrá toda la documentación relacionada con el funcionamiento de los mismos, con excepción de todos aquellos documentos que estén vinculados a la historia clínica de las personas usuarias. Pues bien, salvo que tales archivos puedan calificarse de archivos de oficina (lo cual parece muy forzado), habrá que concluir que están fuera del sistema archivístico, lo cual sería ciertamente sorprendente, dado el volumen y relevancia de la documentación involucrada. Por ello, y a falta de una exclusión clara por parte del legislador,
} 
b) Archivos de las entidades locales de Andalucía.

c) Archivos de las universidades públicas de Andalucía.

d) Archivos de titularidad y gestión distintas a las contempladas en los apartados anteriores integrados en el Sistema Archivístico de Andalucía.

Asimismo, la Ley 7/2011 no ha previsto regla alguna para la creación de nuevos archivos de titularidad autonómica, cuando la práctica ha demostrado que en ocasiones se crean archivos al margen de los órganos del sistema ${ }^{67}$. Por ello, habría sido interesante exigir un Decreto del Consejo de Gobierno, y el informe de la Consejería competente en materia de archivos, salvo naturalmente que ésta formule la propuesta.

B. El Archivo del Parlamento de Andalucía y los archivos de las instituciones de autogobierno

El Proyecto de Ley presentado para su tramitación parlamentaria establecía que el Archivo General de Andalucía es el archivo histórico, entre otras instituciones, del Parlamento de Andalucía. Sin embargo, la Mesa de la Diputación Permanente del Parlamento de Andalucía había adoptado el 9 de julio de 2009 el Acuerdo de "considerar necesario el reconocimiento legal del carácter de archivo histórico en materia parlamentaria para el archivo del Parlamento de Andalucía, manifestándose, sin embargo, a favor de que la documentación producida y recibida por el Parlamento de Andalucía en el ejercicio de sus funciones no sea transferida a ningún órgano dependiente de otra administración".

A partir de este acuerdo, en el trámite parlamentario del Informe de la Ponencia se introdujeron varias enmiendas en el texto orientadas a independizar el archivo del Parlamento del Archivo General de Andalucía, para lo cual se obliga a la Ley -art. 41- a diferenciar dentro de los archivos de la Junta de Andalucía, de un lado, al Archivo del Parlamento de Andalucía, y de otro, los «Archivos de titularidad y gestión de la Junta de Andalucía» (como si el Archivo

parece preferible entender que tales archivos, en la medida en que contienen documentación de titularidad pública en poder de órganos o entidades integradas o dependientes de la Administración de la Junta de Andalucía, forman parte de dicho sistema. Otra cosa será el alcance de las competencias de coordinación de la Consejería competente en materia de archivos, pero esa es ya una cuestión orgánica.

${ }^{67}$ Así, p. ej., por Orden de la Consejería de Justicia y Administración Pública de 26 de diciembre de 2000, por la que se regulan los expedientes personales correspondientes al personal al servicio de la Junta de Andalucía, se estableció que los órganos competentes de personal debían revisar los expedientes personales existentes, manteniendo durante un año en sus archivos los de aquéllos que hayan producido baja definitiva, trasladándolos posteriormente al Archivo de la Función Pública, cuyos responsables, de conformidad con las disposiciones en la materia, lo remitirán al Archivo Central de la Consejería. 
del Parlamento de Andalucía no fuese también un archivo de titularidad y gestión de la Junta de Andalucía). Ahora bien, al desaparecer el archivo del Parlamento de Andalucía del artículo 42 referido también a las instituciones de autogobierno, se da la circunstancia de que el Archivo del Parlamento se ha quedado sin regulación en el articulado. Lo único que se puede afirmar, debido a su omisión de los artículos 42 y 45, es que el archivo del Parlamento no tiene que transferir sus fondos al Archivo General de Andalucía ${ }^{68}$.

Por lo demás, la Ley 7/2011 -art. 42- establece que las instituciones de autogobierno de la Comunidad Autónoma reseñadas en el capítulo VI del título IV del Estatuto de Autonomía para Andalucía existirá un archivo, el cual transferirá sus documentos al Archivo General de Andalucía -arts. 42 y 45-.

\section{Archivos centrales}

La Ley 3/1984, de 9 de enero, de Archivos de Andalucía, no contempló expresamente a los archivos centrales de la Administración de la Junta de Andalucía, pero fueron creados por el Decreto 233/1989, de 7 de noviembre, por el que se establece el funcionamiento de los archivos centrales de las consejerías, organismos autónomos y empresas de la Junta de Andalucía y su coordinación con el Archivo General de Andalucía ${ }^{69}$. Por su parte, la Ley 7/2011 -art. 43.2- confirma las normas anteriores, al establecer que en cada Consejería de la Administración de la Junta de Andalucía, existirá un archivo central. Estos archivos transferirán sus documentos al Archivo General de Andalucía. De este modo, la Ley mantiene el sistema establecido por los Decretos 323/1987 y 233/1989.

De otro lado, como ya se deducía de la propia denominación del Decreto 233/1989, éste extendió la creación de los archivos centrales a organismos autónomos y empresas de la Junta de Andalucía ${ }^{70}$. Sin embargo, así como la creación

\footnotetext{
${ }^{68}$ Lo que sí se ha incluido es una disposición adicional (primera, Garantía de la autonomía parlamentaria), según la cual el Parlamento de Andalucía ejercerá respecto a su archivo, dado su carácter de archivo histórico en materia parlamentaria, todas las competencias normativas precisas para la gestión de sus fondos documentales de acuerdo con la autonomía que le garantiza el artículo 102 del Estatuto de Autonomía para Andalucía.

${ }^{69}$ Ya el Decreto 323/1987, de 23 de diciembre, por el que se crea el Archivo General de Andalucía, dispuso que «En todas las Consejerías de la Junta de Andalucía existirá un archivo central que dependerá funcionalmente de la Consejería de Cultura, en los términos que reglamentariamente se determine, existiendo un Director al frente de cada uno de ellos» - art. 5-.

${ }^{70}$ En tal sentido, el Decreto 233/1989 estableció: «Cada Consejería, Organismo Autónomo y Empresa de la Junta de Andalucía ha de tener un archivo central que cuidará y conservará los documentos
} 
de los archivos centrales de las Consejerías es desde hace tiempo una realidad, no ha sucedido así en relación con los archivos de todas las entidades instrumentales del sector público andaluz ${ }^{71}$.

Por su parte, la Ley 7/2011 -art. 43.3- establece que en cada entidad instrumental dependiente de la Administración de la Junta de Andalucía, existirá un archivo central. Desde un punto de vista formal, debe destacarse que la Ley 7/2011 abandona la referencia de las normas precedentes a los organismos autónomos y empresas públicas, sustituyéndola por la noción genérica de entidades instrumentales, que entendemos que debe interpretarse conforme a la Ley 9/2007, de 22 de octubre, de Administración de la Junta de Andalucía - art. 50-72. Asimismo, a partir de la enmienda núm. 57 del Grupo Socialista, se asignó la coordinación funcional de los archivos centrales de las entidades instrumentales expresamente al Archivo General de Andalucía -art. 43.6- ${ }^{-73}$.

De otro lado, el ordenamiento anterior a la Ley 7/2011 dejaba en una situación de indefinición a los archivos de los órganos territoriales, principalmente de las Delegaciones Provinciales de las Consejerías ${ }^{74}$. Por su parte, la Ley 7/2011 - art. 43- establece lo siguiente: «En cada Delegación del Gobierno de la Junta de Andalucía, así como en cada Delegación Provincial de las res-

desde su creación hasta su eliminación o transferencia al Archivo General de Andalucía, ejerciendo, en los límites de su competencia las actividades archivísticas necesarias a tal fin» -art. 1-.

${ }^{71}$ Así, una década después, el Plan General de Bienes Culturales de 2000 todavía se vio obligado a incluir entre sus objetivos el de completar la red de archivos de servicios centrales.

72 No obstante, la utilización de la expresión «entidad instrumental dependiente de la Administración de la Junta de Andalucía» plantea un problema, pues deja técnicamente deja fuera a una serie de entidades públicas vinculadas a la Administración de la Junta de Andalucía, pero que no pueden calificarse de entidades instrumentales. En efecto, la propia Ley 9/2007, de 22 de octubre, de Administración de la Junta de Andalucía, contempla a Entidades con régimen de independencia funcional o de especial autonomía, vinculadas a la Administración de la Junta de Andalucía (disposición adicional segunda).

${ }^{73} \mathrm{Sin}$ embargo, esta regla no es del todo coherente con el proceso de transferencias establecido en la Ley $7 / 2011$, la cual diferencia entre entidades instrumentales que ejerzan sus competencias en más de una provincia (las cuales transferirán sus documentos al Archivo General de Andalucía - arts. 43.3 y 45-), y entidades instrumentales que ejerzan sus competencias en una sola provincia (las cuales garantizarán el ingreso de los documentos en sus archivos provinciales intermedios correspondientes - arts. 43.3 44.3-).

${ }^{74}$ El Decreto 323/1987 dispuso - art. 6- que «a la documentación generada por los Servicios Periféricos de la Administración Autonómica será de aplicación lo dispuesto en los artículos anteriores, a cuyos efectos, los Archivos Históricos Provinciales cumplirán las funciones asignadas al Archivo General de Andalucía». De este modo, se obligó a los Archivos Históricos Provinciales a realizar la función de archivo intermedio a nivel provincial. Por ello el Plan General de Bienes Culturales de 2000 señaló entre sus objetivos el siguiente: «Solucionar la falta de infraestructura existente en los servicios periféricos de la Junta de Andalucía».

Revista Andaluza de Administración Pública

ISSN: 0034-7639, núm. 82, Sevilla, enero-abril (2012), págs. 13-72 
pectivas Consejerías, existirá asimismo un archivo central. Estos archivos transferirán sus documentos a los archivos provinciales intermedios». Este precepto presenta el indudable acierto de consagrar la naturaleza de archivo central de los archivos de las Delegaciones Provinciales ${ }^{75}$.

En cuanto a la coordinación funcional de estos archivos, como es sabido, en la actualidad Decreto 97/2000 de hacer cargar a los ya saturados Archivos Históricos Provinciales con esta función ${ }^{76}$. Por su parte, la Ley 7/2011 -art. 43.1- establece que los archivos centrales de las Consejerías «llevarán a cabo la coordinación funcional de los archivos centrales de sus respectivos órganos territoriales reseñados en el apartado 4». Es decir, los archivos centrales de las Delegaciones Provinciales de cada Consejería debían ser coordinados por archivo central de la correspondiente Consejería. Sin embargo, la idoneidad de esta atribución es cuestionable, pues la documentación de estos archivos se remite a los futuros archivos provinciales intermedios -art. 44 Ley-.

D. Los archivos provinciales intermedios

Hace ya años que los archivos históricos provinciales presentan un serio problema de la falta de espacio por saturación debido a la necesidad de recibir la documentación de los órganos territoriales de la Administración de la Junta de Andalucía y sus entidades instrumentales ${ }^{77}$. A este respecto una de las mayores novedades de la Ley es justamente la creación en cada provincia de un archivo provincial intermedio para la organización territorial de la Administración de la Junta de Andalucía y de sus entidades instrumentales.

A los archivos provinciales intermedios se transferirán (de acuerdo con los plazos establecidos por la Comisión Andaluza de Valoración y Acceso a los Documentos) los documentos remitidos por los archivos centrales de la organización territorial de la Administración de la Junta de Andalucía y de las entidades instrumentales en su respectiva provincia. Y, a su vez, los archivos pro-

\footnotetext{
75 No obstante, el precepto puede suponer en el futuro una rigidez, pues no cabe descartar en el futuro una posible reorganización de la Administración periférica, en el sentido de integración orgánica, tal como han efectuado otras Comunidades Autónomas.

76 Ya el Plan General de Bienes Culturales, Andalucía 2000, p. 91, señaló la conveniencia de redistribuir las tareas coordinadoras, restando la atribución encomendada a algunos archivos sobrecargados en sí mismos, "como es el caso de los Archivos Históricos Provinciales respecto de los locales".

77 En el PECA 2007-2011 se puede leer: «aún se detectan aspectos de mejora en cuanto a la coordinación con otras Administraciones y especialmente vinculados a la inexistencia de un subsistema de archivos para la Administración periférica de la Junta de Andalucía a la que se une la insuficiencia de estructuras orgánicas provinciales de las propias consejerías en materia de archivos».
} 
vinciales intermedios transferirán a los Archivos Históricos Provinciales aquellos documentos calificados de conservación permanente. La Ley añade que los archivos provinciales intermedios serán coordinados funcionalmente por el Archivo General de Andalucía - art. 44.4-, sin embargo, tal vez debería haberse atribuido esta coordinación funcional a los Archivos Históricos Provinciales pues son los destinatarios de sus fondos.

En todo caso, la Ley 7/2011 condiciona la puesta en funcionamiento de los archivos provinciales intermedios a la aprobación por el Consejo de Gobierno, en el plazo de tres años desde la entrada en vigor de esta Ley, de un Plan de Implantación de los Archivos Provinciales Intermedios, «de acuerdo con los recursos existentes y las necesidades en materia de documentos y archivos de la Administración territorial autonómica» (disposición adicional 8 $8^{\mathrm{a}}{ }^{78}$. El plazo es evidentemente excesivo, pues no se trata de implantar los ocho Archivos Provinciales Intermedios en dicho plazo, sino tan sólo de aprobar el Plan, que tendrá, a su vez, el plazo de ejecución que se disponga ${ }^{79}$.

\section{E. Archivo General de Andalucía}

El Archivo General de Andalucía, previsto en la Ley 3/1984 - art. 13.1-, fue creado mediante Decreto 323/1987, de 23 de diciembre ${ }^{80}$. Por su parte, la Ley 7/2011 - art. 45- se limita a establecer que el Archivo General de Andalucía es el archivo intermedio e histórico para los archivos siguientes: archivos centrales de cada Consejería de la Junta de Andalucía; archivos centrales de las entidades instrumentales de la Administración de la Junta de Andalucía que ejerzan sus competencias en más de una provincia; y archivos de las instituciones de autogobierno de la Comunidad Autónoma reseñadas en el capítulo VI del título IV del Estatuto de Autonomía para Andalucía.

Estos archivos transferirán al Archivo General de Andalucía sus documentos de acuerdo a los plazos establecidos por la Comisión Andaluza de Valora-

${ }^{78}$ El Grupo Popular formuló la enmienda núm. 54, en la que se propuso la supresión de este inciso, razonando que «si depende de los recursos existentes, nunca se pondrá en marcha».

${ }^{79}$ El Grupo Socialista formuló la enmienda núm. 58, en virtud de la cual se adiciona la disposición transitoria siguiente: «Hasta la entrada en funcionamiento de los archivos provinciales intermedios, los archivos históricos provinciales seguirán ejerciendo las funciones establecidas en el artículo 6 del Decreto 233/1987, de 23 de diciembre, por el que se crea el Archivo General de Andalucía».

${ }^{80}$ Sin embargo, lo cierto es que el Archivo General de Andalucía ha carecido de centro propio, debiendo compartir precariamente la sede del Archivos Histórico Provincial de Sevilla. Todavía el Plan General de Bienes Culturales, Andalucía 2000, p. 94, postulaba la ubicación del Archivo General de Andalucía en el Monasterio de San Isidoro del Campo, previsión que también se incumplió. 
ción y Acceso a los Documentos, o en su defecto en el plazo que reglamentariamente se establezca - arts. 43.5 y 45-. Por tanto, la Ley mantiene el criterio del Decreto 323/1987 según el cual el Archivo General de Andalucía cumple la doble función de archivo intermedio y de archivo histórico ${ }^{81}$. Por lo demás, a diferencia de otras leyes autonómicas, no se define al Archivo General de Andalucía como centro cabecera del sistema archivístico, papel que parece haber asumido la Consejería ${ }^{82}$.

\section{F. Archivos Históricos Provinciales}

Como es sabido, los Archivos Históricos Provinciales son de titularidad estatal y, por tanto, de competencia exclusiva del Estado, si bien es posible concertar su gestión con la Comunidad Autónoma ${ }^{83}$. Ahora bien, las normas autonómicas se ven obligadas a reconocer que estos archivos están regidos únicamente por la legislación del Estado, pues las competencias autonómicas, en su caso, se ciñen al ámbito de la gestión ${ }^{84}$. Pues bien, la Ley 7/2011 no introduce (tampoco podría, por lo que se ha dicho) grandes novedades. Según la Ley - art. 46.1-, los archivos históricos provinciales radicados en Andalucía son los archivos históricos de la organización territorial de la Administración de la Junta de Andalucía y de las entidades instrumentales en su respectiva provincia. A los Archivos Históricos Provinciales se transfieren los documentos de conservación permanente procedentes de los archivos siguientes: de los respectivos archivos provinciales intermedios -arts. 44.4 y 46.4-; de la Administración de Justicia en Andalucía ubicada en su provincia, salvo en el caso de los documentos del Tribunal Superior de Justicia de Andalucía, los cuales se trans-

\footnotetext{
${ }^{81}$ Sin embargo, no puede dejar de señalarse que si bien hasta ahora, debido al carácter reciente de la Junta de Andalucía, esta doble función se ha podido desempeñar sin dificultad, en un futuro podrá ser conveniente disociar ambas funciones, tal como ha efectuado alguna Comunidad Autónoma.

${ }^{82}$ En este sentido, el PECA (pág, 4) declaró «necesario reforzar la estructura administrativa que permita llevarlas a cabo, sobre todo teniendo en cuenta que la cabecera del Sistema Andaluz de Archivos radica en la propia Consejería. Es necesario igualmente redefinir el papel del Archivo General de Andalucía (AGA), como el principal centro archivístico propio de la comunidad autónoma». Por lo demás, después de 24 años de su creación, el AGA sigue sin contar con sede propia definitiva.

83 Así, en Andalucía, la transferencia a la Junta de Andalucía de la gestión de los archivos históricos provinciales radicados en Andalucía (y del Archivo de la Real Chancillería de Granada) tuvo lugar por Convenio con el Ministerio de Cultura de 9 de octubre de 1984, actualizado por un nuevo Convenio de 23 de mayo de 1994.

${ }^{84}$ Así, el Decreto 97/2000 declara que se aplicará a todos los archivos integrados en el Sistema Andaluz de Archivos, sin perjuicio de la aplicación a los archivos de titularidad estatal y gestión autonómica de la legislación estatal y, en su caso, de lo dispuesto en los convenios de gestión que, en relación con los citados archivos, estén suscritos por la Administración General del Estado y la Administración de la Junta de Andalucía que tengan por objeto los archivos de titularidad estatal y gestión autonómica -art. 2.1-.
} 
fieren al Archivo de la Real Chancillería de Granada, como archivo de carácter histórico - arts. 46.3, 48.3 y 47.1-.

Las principales novedad para los Archivos Históricos Provinciales son de carácter indirecto. De un lado, son evidentemente los principales beneficiarios de la creación de los archivos provinciales intermedios, de modo que dejan de cumplir esta función de archivo intermedio respecto a la Administración periférica. Y, de otro lado, la Ley 7/2011 establece que los archivos centrales de las Consejerías llevarán a cabo la coordinación funcional de los archivos centrales de sus respectivos órganos territoriales - art. 43.6-, liberándose también a los Archivos Históricos Provinciales de esta función ${ }^{85}$.

\section{Otros archivos del Sistema Archivístico de Andalucía}

\section{A. Archivos de las entidades locales de Andalucía}

Aun cuando la Ley 7/2011 no lo declare de modo expreso, a partir de la Ley 5/2010, de 11 de junio, de Autonomía Local de Andalucía es indudable la competencia de Ayuntamientos y Diputaciones sobre sus archivos ${ }^{86}$. Por su parte, la Ley 7/2011 establece que las «entidades locales de Andalucía garantizarán la prestación de los servicios de archivo dentro de su ámbito territorial», y añade que «Cada entidad local establecerá su propia red de archivos que incluirá los de sus entes vinculados o dependientes»-art. 49.2-. El mandato no es novedoso, pues ya el Decreto 97/2000, de 6 marzo, dispuso que las entidades locales, sin perjuicio de sus potestades organizativas, constituirán sus redes de archivos de acuerdo con el ciclo vital de los documentos - art. 24.1-. Asimismo, debe observarse que Ley no se refiere a los Municipios y Provincias, sino a las «entidades locales» en general, por lo que este mandato legal alcanza también a las Mancomunidades y, en su caso, a los consorcios, tan importantes en la Comunidad andaluza ${ }^{87}$. De otro lado, la red de archivos de cada en-

85 Según el Decreto 97/2000, de 6 marzo, corresponde a los Archivos Históricos Provinciales, de acuerdo con las directrices emanadas de la Consejería de Cultura, la coordinación técnica de los archivos de las Delegaciones Provinciales de la Junta de Andalucía -art. 23.5-.

${ }^{86}$ Así, la Ley 5/2010 - art. 9.17- declara que la competencia propia en materia de cultura incluye la elaboración, aprobación y ejecución de planes y proyectos municipales en materia de archivos (y bibliotecas, museos y colecciones museográficas). Y una de las escasas competencias materiales propias que la Ley 5/2010 atribuye a las Diputaciones Provinciales es la competencia sobre los «archivos de interés provincial» - art. 15.3-

${ }^{87}$ La naturaleza jurídica de los consorcios ha sido siempre muy controvertida, pero la Ley 5/2010 de Autonomía Local establece los consorcios participados mayoritariamente por entidades locales y que persigan fines en materia de interés local se considerarán entidades locales de cooperación territorial a los 
tidad local debe incluir los archivos de sus «entes vinculados o dependientes», expresión que coincide con la empleada por la Ley 5/2010 de Autonomía Local de Andalucía - art. 33.2-, por lo que debe interpretarse en el sentido establecido en esta norma.

Ahora bien, la Ley deja absolutamente indeterminada la estructura de las redes de archivos locales. No obstante, lo cierto es que un «conjunto de archivos» -arts. 2.k) y 33.2- requiere, al menos, dos archivos, y necesariamente deberán existir archivos de oficina (es decir de las unidades que generan la documentación) y un archivo con funciones de archivo histórico, es decir, de custodia y conservación de los documentos calificados como de conservación permanente -art. 2.j)-. La existencia de archivos centrales e intermedios queda, por tanto, remitida a la potestad organizatoria de las entidades locales, en función de las dimensiones de su estructura organizativa y el volumen de producción documental, pues la estructura de la red debe adaptarse a la complejidad organizativa de la entidad titular.

Pero, sobre todo, el aspecto más novedoso de la Ley 7/2011 es el precepto según el cual los archivos «de las diputaciones provinciales y de los ayuntamientos de municipios con más de 15.000 habitantes deberán estar a cargo de personal con la cualificación y nivel técnico que sea necesario, de acuerdo con la normativa que resulte de aplicación» - art. 49.3-. Frente a este precepto debe recordarse que el Decreto 97/2000 - art. 127- establece que en los archivos de la Administración Local, corresponderá a sus órganos competentes determinar la titulación superior o media del archivero o de la archivera que esté al frente de aquéllos. Por el contrario, el precepto de la Ley 7/2011 supone habilitar a la Administración autonómica para determinar la cualificación del personal de los archivos de estos Municipios ${ }^{88}$. Ahora bien, si esto es así, cabe preguntarse ¿qué añade este precepto al artículo 39.1, donde ya se dice, con carácter general, que reglamentariamente se establecerán la cualificación y el nivel técnico necesarios del personal técnico con funciones archivísticas que preste servicio en los archivos del Sistema Archivístico de Andalucía?

efectos de esta ley -art.78.3-. Por el contrario, no parece que las entidades locales descentralizadas -arts. 112 y siguientes Ley 5/2010- deban disponer de servicio de archivo, sino que su fondo documental debe entenderse que forma parte de la red de archivos del municipio al que estén adscritas.

88 Por el contrario, el Grupo Popular formuló la enmienda núm. 36, en la cual se propuso la siguiente redacción: «En los archivos de la Administración Local, corresponderá a sus órganos competentes determinar la titulación y formación del personal con que deban estar dotados». Es decir, desaparecía la previsión de una normativa que fijara el nivel de formación. 
Lo cierto es que otras leyes autonómicas han dado un paso más abierto en el sentido de establecer los ayuntamientos de municipios a partir de cierto número de habitantes están obligados a tener un servicio de archivo propio, dotado de personal archivero con la titulación correspondiente y de instalaciones adecuadas para conservar los documento. De este modo, se configura el servicio de archivo como un servicio municipal mínimo, naturalmente si perjuicio de que todos los ayuntamientos y las demás administraciones locales pueden crear y gestionar su propio archivo ${ }^{89}$.

De otro lado, se planea la cuestión de los pequeños (y no tanto) Municipios que tienen dificultades para mantener un archivo propio. A este respecto, la Ley 4/1984 contemplaba una previsión audaz: «En ámbitos territoriales superiores al municipal, la Consejería de Cultura podrá designar archivos que, con carácter de histórico y situados en el municipio que ofrezca las condiciones más idóneas, reúnan la documentación de otros municipios del entorno que no presenten las condiciones adecuadas de conservación, seguridad y acceso» - art. 13.2- . Ni que decir tiene que esta medida de concentración a la francesa quedó inédita debido a la propia dinámica de la política local. A este respecto, la Ley 7/2011 opta por una previsión mucho más débil, según la cual las entidades locales podrán mancomunarse para la prestación de los servicios de archivo -art. 49.4-, previsión además superflua, pues ya se contempla en la legislación general de régimen local ${ }^{90}$.

De otra parte, la Ley 7/2011 -art. 49.5- obliga a la Administración de la Junta de Andalucía a promover el establecimiento de medidas que contribuyan a la conservación del Patrimonio Documental de Andalucía y a la prestación de los servicios de archivo de las entidades locales. Se trata de un mandato vago que apenas añade nada al artículo 37.1, el cual establece, con carácter general, que la consejería podrá establecer medidas de fomento y de apoyo técnico y económico, a las que podrán acceder las personas titulares de los archivos ubicados en Andalucía. De hecho, lo más significativo en este aspecto es la ausencia de atribución específica a las diputaciones provinciales de competencia cooperativa respecto a los archivos municipales, si bien

\footnotetext{
${ }^{89}$ Más de diez mil habitantes en los casos de la Ley de Cataluña 10/2001 - art. 31.1-, Ley de la Comunidad Valenciana 3/2005 - art. 36.1-(y Diputaciones), y Ley de Extremadura 2/2007 -art. 36.2-.

${ }^{90}$ En la actualidad, la Ley 5/2010 de Autonomía Local de Andalucía establece que los municipios tienen derecho a asociarse entre sí, constituyendo mancomunidades, para la planificación, establecimiento, gestión o ejecución en común de obras y servicios determinados de competencia propia - art. 63.1-. De hecho, el Grupo Popular formuló la enmienda núm. 37, en la que se propuso la supresión de este apartado.
} 
deben entenderse vigentes las competencias genéricas de asistencia a los municipios reconocidas en la Ley 5/2010, de 11 de junio, de Autonomía Local de Andalucía - arts. 11 y ss.- .

\section{B. Archivos de las universidades públicas de Andalucía}

Debido a la autonomía constitucionalmente reconocida a las Universidades públicas -art. 27.10 CE--, los archivos de estas entidades no pueden considerarse como dependientes de la Administración autonómica, sino que, de modo similar a los archivos de las Entidades Locales, han de reputarse como archivos constitutivos de un subsistema autónomo ${ }^{91}$. Por su parte, la Ley 7/2011 se limita a establece que las universidades públicas de Andalucía establecerán su propia red de archivos que incluirá los de sus entidades instrumentales -art. 50-, así debe señalarse la práctica extendida de creación por parte de las Universidades de fundaciones. Por lo demás, es aplicable la antes indicada con ocasión de los archivos de las entidades locales indefinición de la red de archivos.

\section{Otros Archivos}

La Ley 3/1984 - art. 9.2- pretendió estructurar el Sistema Andaluz de Archivos a partir de la noción de "archivos de uso público", entendiendo por tales todos los archivos titularidad pública de competencia autonómica, así como «los de titularidad privada que reciban de los poderes públicos subvenciones o ayudas en cuantía superior a la mitad de su presupuesto ordinario»-art. 11-, sin perjuicio de la voluntaria integración en el sistema de otros archivos de titularidad privada - art. 9.2-. No obstante, aun cuando el Decreto 97/2000 -art. 16.1 siguió haciendo mención a esta integración por mandato legal -art. 26.3-, en la práctica, no consta que se haya hecho uso de esta disposición ${ }^{92}$.

\footnotetext{
${ }^{91}$ En este sentido, el Decreto 97/2000 declaró que son archivos de titularidad universitaria los de las Universidades de Andalucía, así como los de las dependencias o servicios adscritos a aquéllas -art. 20-y, al igual que en relación con las Entidades Locales, admitió que las Universidades, como entes autónomos, constituyan sus propias redes de archivos, "de acuerdo con el ciclo vital de los documentos" -art. 25-.

92 Incomprensiblemente, el Decreto 97/2000 - art. 26- remitió a Orden de la Consejería la ordenación del procedimiento para solicitar la integración de los archivos de titularidad privada en el sistema andaluz de archivos, limitándose a regular la documentación a acompañar a la solicitud. Finalmente, la Orden de 16 de junio de 2004, por la que se regula el procedimiento para la integración de archivos de titularidad privada en el Sistema Andaluz de Archivos, se ve obligada a declarar que los Archivos de titularidad privada que se consideren de uso público por aplicación de lo dispuesto en el artículo 11 de la Ley 3/1984, de 9 de enero, quedan integrados en el Sistema Andaluz de Archivos de acuerdo con el artículo 21 del Decreto 97/2000, de 6 de marzo, por lo que no les resulta de aplicación el procedimiento establecido en esta Orden - art. 2.2-.
} 
Por su parte, según la Ley 7/2011, la inclusión de un archivo distinto de los contemplados en las secciones anteriores en el Sistema Archivístico de Andalucía se producirá a petición de las personas físicas o jurídicas públicas o privadas interesadas, y se resolverá, en un plazo no superior a seis meses, de acuerdo con el procedimiento y con los requisitos que se establezcan en las normas que desarrollen el procedimiento de integración - art. 51-. En primer lugar, debe observarse que, a diferencia del Decreto 97/2000 el cual sólo contempla la integración de los archivos de titularidad privada en el Sistema Andaluz de Archivos - art. 26-, la Ley 7/2011 habla de peticiones de personas públicas o privadas. Esto es así porque la propia Ley 7/2011 establece que la Comunidad Autónoma colaborará con el Estado para la integración en el Sistema Archivístico de Andalucía de los archivos estatales ubicados en el territorio andaluz -art. 5.3-.

De otro lado, de modo pragmático, se abandona definitivamente la indicada integración ope legis prevista en la Ley 3/1984, siguiendo asimismo el criterio más extendido en la legislación autonómica. En cuanto a la integración en sí misma, como se ha visto, la Ley remite al ámbito reglamentario tanto la determinación de los requisitos (sustantivos y formales) como del procedimiento. Y sorprende que la única determinación de la Ley, no trate sobre los requisitos sustantivos sino sobre el procedimiento. En todo caso, la futura norma reglamentaria que desarrolle a la Ley en este punto deberá rectificar el criterio de la norma reglamentaria vigente, que en lugar de establecer requisitos reglados hacer referencia a unos, en ocasiones vagos, criterios de valoración, que parece conceder a la Administración un cierto margen de apreciación ${ }^{93}$.

En cuanto al procedimiento de integración, como se ha señalado, la Ley 7/2011 se limita a fijar un plazo de seis meses para la resolución (y notificación) del procedimiento, plazo que coincide con el establecido en la actualidad en la vigente norma reglamentaria, y que al no exceder del plazo máximo para los procedimientos que impone la Ley 30/1992 para exigir la reserva de Ley era innecesaria su determinación en la Ley $7 / 2011$. Finalmente, sin perjuicio de determinación normativa de los requisitos que han de cumplir los archivos para poder integrarse en el Sistema, entendemos que el procedimiento debería estar abierto a la terminación convencional, pues de lo que se trata de de favorecer esa integración. Además, en el caso específico de integración de un

\footnotetext{
93 Así la Orden de 16 de junio de 2004, por la que se regula el procedimiento para la integración en el Sistema Andaluz de Archivos, se refiere, entre otros criterios, a «La contribución al acrecentamiento y enriquecimiento del Patrimonio Documental Andaluz, así como la singularidad de los documentos, fondos y/o colecciones constitutivos del Archivo objeto de la integración» -art. 6-.
} 
archivo de titularidad estatal, tal operación debe plasmarse necesariamente en un convenio interadministrativo de colaboración ${ }^{94}$.

\section{El Censo de Archivos de Andalucía}

La Ley 3/1984 - art. 17- dispuso que la Junta de Andalucía procederá a la confección de un censo de archivos y fondos documentales constitutivos del Patrimonio Documental Andaluz, en cada una de las ocho provincias, incluyendo una estimación cuantitativa y cualitativa, así como su estado de conservación y su seguridad. Sin embargo, este mandato tardó casi veinte años en cumplirse $^{95}$.

Por su parte, la Ley 7/2011 -art. 52.1- establece que el Censo de Archivos de Andalucía es el instrumento para la identificación de los archivos radicados en el territorio de la Comunidad Autónoma que custodian documentos integrantes del Patrimonio Documental de Andalucía. Parece evidente que este censo sustituye al previsto en la Ley anterior ${ }^{96}$. No obstante, en tal caso, entendemos que la ubicación sistemática más correcta de esta figura sería en el capítulo referido al Patrimonio Documental de Andalucía, pues es perfectamente posible que existan archivos de titularidad privada incluidos necesariamente en el Censo de Archivos de Andalucía por custodiar documentos integrantes del Patrimonio Documental de Andalucía, pero que, sin embargo, no estén integrados en el Sistema Archivístico de Andalucía, pues tal integración es exclusivamente voluntaria - como nos consta- .

\footnotetext{
${ }^{94}$ Asimismo, en el caso de integración de archivos de la Iglesia Católica, habrá que estar a lo dispuesto en el Acuerdo sobre la constitución, composición y funciones de la Comisión Mixta, Junta de Andalucía y Obispos de la Iglesia Católica de Andalucía para el Patrimonio Cultural, publicado mediante Orden de la Consejería de Cultura de 2 de abril de 1986, y al que se refiere la propia Ley 7/2011 en su disposición adicional tercera.

${ }^{95}$ El propio Parlamento andaluz aprobó el 23 de octubre de 1998 una proposición no de ley en Comisión, promovida por el Grupo Izquierda Unida, instando al Gobierno andaluz a la realización a lo largo de 1999 del censo de archivos y fondos constitutivos del Patrimonio Documental Andaluz (BOPA núm. 274, de 24-11-1998). Así, el Plan General de Bienes Culturales, Andalucía 2000, p. 91, fijó justamente como primera medida la elaboración del Censo de Archivos Andaluces. Por acuerdo del Consejo de Gobierno de 14 de noviembre de 2000 se aprobaron las directrices para la elaboración del censo de fondos y colecciones del Patrimonio Documental Andaluz -en cumplimiento de la previsión contenida en la disp. adicional $1^{\text {a }}$ del Decreto 97/2000-, y, por Orden de la Consejería de Cultura de 6 de marzo de 2001 se aprobó el Plan para la elaboración del citado Censo, de acuerdo con dichas directrices.

${ }^{96}$ Así, la disposición adicional cuarta establece que a la entrada en vigor de esta ley, los archivos y los documentos, fondos y colecciones censados con arreglo a lo previsto en el artículo 17.1 de la Ley 3/1984, de 9 de enero, de Archivos, quedarán incorporados al Censo de Archivos de Andalucía previsto en el artículo 52 de esta ley.
} 
En cuanto a su contenido, la Ley 7/2011 -art. 52.2- establece que el Censo de Archivos de Andalucía comprenderá la información que permita conocer los datos básicos de todos los archivos contemplados en el apartado anterior dependientes tanto de personas físicas como jurídicas de cualquier naturaleza, y de los documentos en ellos custodiados. Aun cuando, a diferencia de la Ley 3/1984, no se habla ya de censo de fondos documentales, parece defendible que la referencia a los «datos básicos» incluye a los fondos documentales de consta cada archivo. Por lo demás, las normas sobre elaboración y difusión del censo son similares a las anteriores.

\section{LA GESTIÓN DOCUMENTAL}

\section{Concepto y funciones de la gestión documental}

Una de la principales novedades de la Ley 7/2011 es la introducción de la metodología de la gestión documental ${ }^{97}$. Así, debe recordarse que uno de los objetos de la Ley es precisamente regular la gestión de los documentos de titularidad pública y del Patrimonio Documental de Andalucía -art. 1-.

Ciertamente, ya el Decreto 97/2000 había dado carta de naturaleza al principio del ciclo vital de los documentos o teoría de las edades documentales, pero en la economía del Decreto el ciclo vital de los documentos tiene por principal efecto determinar las redes de archivos - art. 16.2- y con ellas las transferencias regulares de documentación - art. 50-. De este modo, aun cuando se intenta involucrar a las unidades de gestión administrativa en algunas funciones archivísticas -como la identificación y valoración documental (arts. 27.2 y 29.2 Decreto 97/2000)-, lo cierto es que el sistema archivístico no alcanza, apenas, a penetrar en la gestión administrativa, deteniéndose en la gestión archivística en sentido estricto.

Por su parte, la Ley 7/2011 -arts. 2.m) y 53-define la gestión documental como el conjunto de funciones y procesos reglados, aplicados con carácter transversal a lo largo del ciclo vital de los documentos, para garantizar el acceso y uso de los mismos, así como para la configuración del Patrimonio Documental de Andalucía ${ }^{98}$. Según la 7/2011 -art. 54.1-, la gestión documental

\footnotetext{
${ }^{97}$ Es mérito de la Ley de Cataluña 10/2001 la introducción en una norma legal del concepto de sistema de gestión documental.

98 Sobre el ciclo vital de los documentos nos remitimos a lo indicado más arriba a propósito de las redes de archivo.
} 
está integrada por las siguientes funciones archivísticas aplicadas a los documentos: la identificación, la valoración, la organización, la descripción, la conservación, la custodia, el acceso y el servicio ${ }^{99}$. Pero, además, la Ley explicita que la gestión documental implicará el diseño mismo de los documentos, para garantizar su autenticidad, fiabilidad, integridad, disponibilidad y contextualización, requisitos que la ley impone a los documentos de titularidad pública -art. 11.1-. Además, la gestión documental implica la definición de los sistemas de información, con el fin de garantizar la capacidad de estos sistemas para generar los metadatos necesarios que han de asociarse al documento para su adecuada gestión archivística - art. 54.2-, pues son los metadatos los que precisamente posibilitan la exigencia de contextualización de los documentos.

Por ello, la Ley recalca la idea según la cual gestión documental (en el ámbito de la Junta de Andalucía) es común e integrada en la gestión administrativa -art. 56.1-. Pero, sobre todo, la Ley 7/2011 insiste en el carácter transversal de la gestión documental, «ya que participan en la misma todas las personas responsables de la gestión administrativa y se aplica a todos los ámbitos de actividad»-art. 2.m)-100. Y, del mismo modo, en el carácter transversal de las funciones archivísticas recogidas en el artículo 54 y los principios archivísticos de respeto al origen y al orden natural de los documentos aplicados a lo largo del ciclo vital de los mismos con independencia de su productor -art. 4.3-.

Por lo demás, la Ley 7/2007 -art. 55- establece que las indicadas funciones de la gestión documental se aplicarán en todos los archivos del Sistema Archivístico de Andalucía. Las administraciones públicas andaluzas establecerán en sus respectivos ámbitos el uso de sistemas de información para la gestión de los documentos de titularidad pública, de conformidad con las funciones de la gestión documental - referidas en el artículo 54-, con las normas archivísticas y con los principios técnicos que establezca la consejería ${ }^{101}$.

\footnotetext{
${ }^{99}$ Ignoramos por qué no se ha incluido la eliminación de los documentos, que constituye una evidente operación de gestión documental.

100 Reitera este idea la Ley, en sede de la gestión documental en el ámbito de la Junta de Andalucía, al declarar que, de acuerdo con el carácter transversal de la gestión documental, en las funciones y procesos reglados de esta participarán todas las personas responsables de la gestión administrativa y de la custodia de los documentos de titularidad pública - art. 56.2-.

101 Según dispone la Ley, corresponde a la consejería competente en la materia, como órgano de dirección y coordinación del Sistema Archivístico de Andalucía la elaboración y, en su caso, aprobación de las disposiciones normativas referentes a los archivos que integran el Sistema Archivístico de Andalucía y de las normas técnicas y procedimientos para la gestión documental -art. 29.2.a)-. Asimismo, debe recordarse que quienes ostenten la titularidad de los archivos del Sistema Archivístico de Andalucía están
} 
De este modo, aun cuando se declara que las funciones de la gestión documental se aplicarán en todos los archivos del Sistema Archivístico de Andalucía, el mandato a implantar sistemas de información para la gestión de los documentos se circunscribe a las administraciones públicas andaluzas (principalmente entidades locales y universidades públicas, pues la Administración de la Junta de Andalucía cuenta con una regulación propia). Y lo cierto es que lo razonable es vincular la gestión documental a los documentos de titularidad pública, pues éstos forman parte del Patrimonio Documental desde el mismo momento en que se generan ${ }^{102}$.

\section{La gestión documental en la Junta de Andalucía}

$\mathrm{Al}$ margen de reiterar las ideas de el carácter transversal de la gestión documental, y de su integración en la gestión administrativa, la Ley 7/2011 -art. 60.2- crea el Sistema de Información de Archivos de la Junta de Andalucía, como sistema común para la gestión integrada de los documentos de su competencia, de acuerdo con los principios y criterios técnicos archivísticos que la rigen, correspondiendo su coordinación a la Consejería en materia de archivos ${ }^{103}$. Así, en otro lugar, la Ley declara que el Sistema Archivístico de Andalucía promoverá un modelo común de gestión documental acorde con la implantación de la administración electrónica, siguiendo los principios de cooperación y colaboración entre las consejerías competentes en materia de documentos, archivos y patrimonio documental, administración electrónica y política informática -art. 27.3-104.

obligados a aplicar las funciones de gestión documental, de acuerdo con lo previsto en esta ley y con las normas técnicas básicas que pueda fijar la consejería - art. 36.1.c) $1^{\mathrm{a}}$.

102 Dicho de otro modo, es razonable que la integración de un archivo privado en el Sistema de Archivos comporte una serie de deberes que atañen a la gestión del archivo correspondiente, pero no a la gestión de los documentos por parte de la entidad privada de la que proceden, pues ello supondría una clara injerencia en la autonomía privada, no exigida por dogmática del Patrimonio Documental. Por todo ello, bien podría haberse incluido esta parte de la Ley dentro del capítulo referido a los documentos de titularidad pública.

${ }^{103} \mathrm{El}$ precedente de este Sistema de Información de Archivos de la Junta de Andalucía se encuentra en la Orden de 20 de febrero 2007, por la que se regula la implantación y uso del Sistema de Información para la Gestión de los Archivos de titularidad y/o gestión de la Junta de Andalucía (proyecto @rchivA Andalucía), que se declara de aplicación a todos los órganos, unidades y archivos de titularidad y/o gestión de la Administración de la Junta de Andalucía, de sus organismos autónomos y empresas públicas. El propio consejero informó en el debate a la totalidad del proyecto de ley que 76 archivos trabajan con este sistema que cuenta ya con más de ocho millones cuatrocientos mil documentos en soporte digital. DSPA Plenos núm. 121, 8 de junio de 2011, pp. 20 y ss.

104 Según la Ley -art. 29.2.c)-, corresponde a la consejería competente en la materia el diseño, implantación y coordinación de un sistema de información de archivos para la gestión documental de la Junta de Andalucía y el impulso para su extensión, en su caso, a los demás archivos integrados en el Sistema Archivístico de Andalucía.

Revista Andaluza de Administración Pública

ISSN: 0034-7639, núm. 82, Sevilla, enero-abril (2012), págs. 13-72 
El Sistema de Información de Archivos de la Junta de Andalucía interoperará con el resto de sistemas de información de la Junta de Andalucía para gestionar la transferencia de la custodia de los documentos electrónicos conforme a los plazos establecidos. También interoperará con el sistema en el que se almacenen los documentos electrónicos de la Junta de Andalucía para facilitar el acceso y uso de los documentos que en él se custodian ${ }^{105}$. Por lo demás, puede señalarse que los reglamentos de régimen interior de algunas de las nuevas agencias públicas aprobadas están recogiendo la implantación de sistemas de gestión documental ${ }^{106}$.

\section{EL AGGESO A LOS DOGUMENTOS}

\section{Acceso a los documentos de titularidad pública}

Tras un par de preceptos perfectamente superfluos -arts. 61 y 62.1-, la Ley 7/2011 establece lo siguiente: «El acceso a los documentos que contengan datos personales que puedan afectar a la seguridad de las personas, a su honor, a la intimidad de su vida privada y familiar y a su propia imagen queda reservado a las personas titulares de esos datos o a quienes tengan su consentimiento expreso. Sin perjuicio de lo dispuesto por la legislación específica, podrán ser consultados cuando hayan transcurrido veinticinco años desde la muerte de los afectados, si la fecha se conoce, o, de lo contrario, a los cincuenta años desde la fecha de los documentos»- art. 62.2-. Como es notorio, este precepto coincide con lo establecido en la LPHE -art. 57.1-.

De este modo, se corrige la redacción de la Ley 3/1984, según la cual en el supuesto de que la información afecte a la seguridad, honor o intimidad de las personas físicas, la consulta de los documentos «no podía realizarse sin consentimiento expreso de los afectados o hasta que transcurran veinticinco años desde el fallecimiento de las personas afectadas o cincuenta años a partir de la fecha de los documentos», lo que parecía admitir que no era necesario el consentimiento cuando indistintamente se diera alguno de los dos supuestos (vein-

105 Además, la Ley crea el Registro General de los Sistemas de Información que produzcan o custodien documentos electrónicos, configurado como el instrumento necesario para el seguimiento y control de la producción y custodia de documentos electrónicos de la Administración de la Junta de Andalucía -art. 59-.

106 Es el caso del Reglamento de Régimen Interior de la Agencia de Medio Ambiente y Agua de Andalucía (BOfA 15-7-2011), que llega a declarar que la estructura básica documental describe y marca el funcionamiento de la Agencia y, por lo tanto, del Sistema de Gestión de la Agencia. 
ticinco años desde el fallecimiento de las personas afectadas «o» cincuenta años a partir de la fecha de los documentos). Por el contrario, la LPHE establece claramente que el plazo de los cincuenta años a partir de la fecha de los documentos sólo es aplicable si se desconoce la fecha del fallecimiento del interesado («o, en otro caso»), redacción a la que ahora se ajusta la Ley $7 / 2011^{107}$.

De otro lado, la Ley 7/2011 -art. 62.3- establece que el «órgano responsable de la custodia de los documentos podrá desestimar la solicitud de acceso a los documentos y a su información cuando la misma no se encuentre en su poder, cuando la solicitud sea manifiestamente irrazonable o cuando esta se formule de manera excesivamente general». Aparentemente, la redacción de este precepto está inspirada en la Ley 27/2006, de 18 de julio, por la que se regulan los derechos de acceso a la información, de participación pública y de acceso a la justicia en materia de medio ambiente -art. 13.1-. No obstante, salvo el caso de solicitud manifiestamente irrazonable, en los otros dos supuestos deben realizarse algunas observaciones.

La citada Ley 27/2006 habilita a denegar las solicitudes de información ambiental cuando «la información solicitada a la autoridad pública no obre en poder de ésta o en el de otra entidad en su nombre», entendiendo la noción de autoridad de un modo amplio, como la entera persona jurídica, mientras que en la Ley 7/2011 basta que la información solicitada órgano no se encuentre en poder del «responsable de la custodia de los documentos». Además, cuando se produzca dicho supuesto, la Ley 27/2006 obliga a remitir la solicitud a la autoridad pública que posea la información y a dar cuenta de ello al solicitante -art. 10.2.b)-. De otro lado, en el caso de que se considere que la solicitud está formulada de manera «excesivamente general», antes de denegar la solicitud por este motivo, la Ley 27/2006 obliga a la autoridad pública a pedir al solicitante que concrete su petición de información y a asistirle en este labor -art. 10.2.a)-. Ninguna de estas cautelas han sido incluidas en la Ley $7 / 2011^{108}$

${ }^{107}$ Con todo, la aplicación del artículo 57.1 LPHE (y ahora del art. 62.2 Ley /2011) es más complicada de lo que parece, pues la aplicación del plazo de los 50 años requiere de un supuesto singular: que conste que el interesado haya fallecido pero no conste la fecha exacta del óbito, porque de conocerse esa fecha sería de aplicación el plazo de 25 años a partir de la misma. Y ciertamente se trata de supuesto difícil, pues si se acredita el fallecimiento generalmente se conocerá la fecha.

108 Sobre la Ley 27/2006, de 18 de julio, véase S. FERNÁNDEZ RAMOS, El derecho de acceso a la información medioambiental, Monografía asociada a la Revista Aranzadi de Derecho Ambiental núm. 15, Aranzadi-Thomson, Gizur Menor, 2009. 
De otra parte, la Ley 7/2011 -art. 62.4- establece que el acceso a los documentos «podrá ser denegado cuando el estado de conservación de los mismos así lo requiera». Igualmente se añade que la obtención de reproducciones de los documentos estará condicionada por su estado de conservación -art. 63.3-109. Ahora bien, dejando al margen el carácter anacrónico de esta limitación, pues las nuevas tecnologías permiten capturar la información contenida en el documento sin riesgo apenas para su conservación, el principal problema que presenta es su alcance aparentemente indefinido, sin que la Ley establezca en tales casos alternativa alguna, a diferencia de otras leyes autonómicas.

En quinto lugar, la Ley 7/2011 -art. 62.5- establece que se «denegará la consulta directa de los documentos originales a las personas que hayan sido condenadas por sentencia firme por la comisión de delitos contra la seguridad y conservación del Patrimonio Documental. Queda exceptuada de esta limitación la consulta de los documentos pertenecientes a procedimientos en los que sean parte interesada». Esta excepción tiene su antecedente en la Ley 3/1984, según la cual podrá denegarse el acceso al patrimonio documental y bibliográfico a las personas que hayan sido sancionadas por su actuación contra la seguridad y conservación de dicho patrimonio (precepto añadido por la Ley 1/1991). Ahora bien, se aprecian importantes diferencias entre ambos preceptos: así en la Ley 3/1984 el presupuesto de la causa de denegación consistía en haber sido sancionado, por lo que bastaba la comisión de una infracción administrativa en materia de patrimonio documental, mientras que en la Ley 7/2011 se exige la condena por sentencia firme por la comisión de delitos contra la seguridad y conservación del Patrimonio Documental, y ciertamente parece razonable reservar a los jueces tan importante efecto sobre el ejercicio de un derecho cívico, y se cuida de exceptuar la consulta a documentos pertenecientes a procedimientos en los que sean parte interesada, pues verse afectado el derecho a la tutela judicial. Pero, además, en la Ley 3/1984 se permitía una denegación genérica del acceso, mientras que la Ley 7/2011, de forma más proporcionada, matiza que se denegará la consulta directa de los documentos originales, por lo que no es excluye el acceso a acopias de los mismos. Por tanto, en este punto la Ley 7/2011 mejora notablemente lo establecido en la ley anterior.

De otro lado, la Ley 7/2011 omite, acertadamente dos reglas contenidas en la Ley 3/1984. En primer lugar, la Ley 3/1984 dispuso que la consulta pública de los documentos de titularidad pública "será posible a partir de los trein-

${ }^{109}$ En este sentido, ya la Ley 3/1984 condicionada la consulta a que no supusiera riesgo para la seguridad de los documentos. 
ta años de haber finalizado su trámite o vigencia administrativa"-art. 27.a)-. Aun cuando parecía evidente que la Ley 3/1984 no establecía que la documentación pública tuviese carácter reservado hasta tanto transcurriera el mencionado plazo de treinta años, la Ley 3/1984 sí parecía, no obstante, conceder una amplísima discrecionalidad a la Administración, al establecer que "se podrá reducir este término temporal siempre que la información no implique riesgo para la seguridad pública o privada" - art. 27.b)-. Este criterio, que pudo ser comprensible en 1984 era del todo inadmisible tras la entrada en vigor de la LRJPAC, pues es evidente que la Administración no disfruta de una potestad discrecional para autorizar o no el ejercicio del derecho, sino que el acceso a la misma estará sujeto a las reglas generales establecidas en el art. 37 de la propia LRJPAC $^{110}$. De este modo, con buen criterio, la Ley 7/2011 ha suprimido toda referencia al plazo de los treinta años.

En segundo lugar, la Ley /2011 omite el precepto de la Ley 3/1984 según el cual no podrá autorizarse la consulta pública cuando la información contenga datos que "pueda afectar a los intereses vitales de Andalucía», y que constituía una cláusula en extremo vaga ${ }^{111}$.

Respecto, al procedimiento de acceso y derecho de obtención de copias de los documentos de titularidad pública, la Ley 7/2011 - art. 63.1- se limita a declarar que el ejercicio del derecho de acceso a los documentos de titularidad pública y obtención de copias de los mismos está sujeto a lo dispuesto en los artículos 37 de la LRJPAC, y 86 de la Ley 9/2007, de 22 de octubre, de la Administración de la Junta de Andalucía, y al procedimiento que se establezca mediante orden por la consejería ${ }^{12}$. Es decir, la Ley renuncia a establecer

\footnotetext{
${ }^{110}$ Ciertamente la ordenación legal del derecho de acceso contenida en la Ley 30/1992 -art. 37- no está exenta de incertidumbres, por las que ha sido ampliamente censurada, pero en modo alguno puede decirse que la Administración esté facultada para admitir o denegar discrecionalmente el ejercicio del derecho de acceso. Vid. S. FERNÁNDEZ RAMOS, El derecho de acceso a los documentos administrativos, Marcial Pons, Madrid, 1997, pp. 361 y ss.

111 FERNÁNDEZ RAMOS, Severiano (2003): 264.

112 Puede recordarse que el artículo 86 de la LAJA, tras declarar que la ciudadanía tiene derecho a acceder a los archivos y registros administrativos en los términos previstos en la normativa básica vigente, establece que el derecho de acceso a los archivos y registros solo podrá ejercerse en relación con procedimientos terminados en la fecha de la solicitud (determinación que coincide con lo establecido en el artículo 37.1 LRJPAC). El derecho de acceso a los archivos y registros administrativos conllevará el de obtener copias o certificados de los documentos cuyo examen sea autorizado por la Administración, previo pago, en su caso, de las exacciones que se hallen legalmente establecidas (determinación que coincide con lo establecido en el artículo 37.8 LRJPAG). El órgano responsable del archivo o registro deberá resolver sobre el acceso en el plazo máximo de un mes desde que se formuló la solicitud, plazo que coincide con el pre-
} 
un procedimiento propio, remitiéndose a las normas generales de procedimiento, así como a una futura orden ${ }^{113}$.

De otro lado, en relación con los instrumentos archivísticos para facilitar el acceso a los documentos de titularidad pública, la Ley 7/2011 - art. 64.1- ordena que para garantizar el ejercicio del derecho de acceso, cada archivo facilitará instrumentos archivísticos de información y descripción y asesorará a las personas usuarias en la búsqueda de la información contenida en el mismo. Las distintas administraciones públicas procurarán los medios tecnológicos y telemáticos necesarios para facilitar, mejorar y ampliar el conocimiento y la difusión de los instrumentos citados en relación con sus documentos. Cuando estos instrumentos contengan datos referidos a personas físicas incluirán la información desagregada por sexo ${ }^{114}$.

Finalmente, debe señalarse que la Ley 7/2011 tipifica dos infracciones relacionadas con el acceso a los documentos. De un lado, tipifica como infracción muy grave permitir el acceso a la información contenida en aquellos documentos que tengan algún tipo de reserva en su acceso o estén restringidos o protegidos por ley -art. 71.c)-. Y, de otro lado, tipifica como infracción grave impedir el derecho de acceso de la ciudadanía a los archivos, «contraviniendo los términos previstos en los artículos 61, 62, 63 y 65». Doble tipificación que sitúa a los responsables de los archivos públicos en una difícil tesitura, sobre todo la vista de los intrincados límites entre el acceso y la confidencialidad de no pocos tipos de documentos, de tal modo que será fácil alegar el error invencible de derecho. Y de aquí la importancia que puede desempeñar en un futuro la Comisión Andaluza de Valoración y Acceso a los Documentos, mediante la indicada función de establecer criterios homogéneos sobre la aplicación de la normativa de acceso - arts. 31.3.b) y $62.6^{-}$.

visto en la Ley de Castilla-La Mancha 19/2002 - art. 35.3-, y que reduce a la mitad el plazo de dos meses establecido en la Ley de Cataluña 11/2011 - art. 35.1-. La denegación deberá motivarse expresamente. Sin embargo, no determina la Ley de Administración de la Junta de Andalucía cuál es el sentido del silencio administrativo en este procedimiento. A este respecto, puede señalarse que tanto la Ley de Cataluña 11/2011 -art. 35.1- como la Ley de Castilla-La Mancha 19/2002 -art. 35.3- optaron por un sentido desestimatorio.

${ }^{113}$ En nuestra opinión, habría sido más adecuada una remisión a un decreto del Consejo de Gobierno, pues no se trata de desarrollar una cuestión orgánica, sino procedimiento mediante el que se ejercita el derecho subjetivo más relevante que reconoce la Ley.

${ }^{114}$ Este precepto parece tener origen en la Ley 12/2007, de 26 de noviembre, para la promoción de la igualdad de género en Andalucía, la cual obliga a incluir sistemáticamente la variable sexo en las estadísticas, encuestas y recogida de datos que realicen -art. 10.1-. No obstante, para no incurrir en una grosera vulneración de la Ley Orgánica 15/1999 de Protección de Datos de carácter Personal, debe entenderse que los datos en cuestión están despersonalizados. 


\section{Acceso a los documentos de titularidad privada}

En esta materia la Ley 7/2011 efectúa una triple distinción: documentos de titularidad privada conservados en archivos públicos, documentos de titularidad privada conservados en archivos privados integrados en el Sistema, y resto de documentos (con una importante restricción). Respecto a los primeros, la Ley 7/2011 -art. 65- establece que el acceso a los documentos de titularidad privada integrantes del Patrimonio Documental de Andalucía que se encuentren depositados en instituciones públicas se regirá por lo dispuesto en los instrumentos que formalizaron el ingreso. Sigue aquí la Ley el criterio del Decreto 97/2000 - art. 92-, según el cual la consulta de documentos pertenecientes a fondos y/o colecciones documentales (se entiende que privados) ingresados mediante depósito en los archivos del Sistema Andaluz de Archivos, se regirá por las condiciones del depósito, sin perjuicio de la observancia de las normas de obligado cumplimiento. Y este inciso final es el que, justamente, falta en la Ley, pues de lo contrario se produciría la paradoja según la cual el acceso de los mismos documentos en archivos privados estaría mejor garantizado en la Ley -tal como se verá seguidamente- .

En segundo lugar, según la Ley 7/2011 -art. 66.1-, el acceso a los documentos de titularidad privada que formen parte del Patrimonio Documental de Andalucía y que se encuentren en archivos privados integrados en el Sistema Archivístico de Andalucía se regirá por las normas de acceso a los documentos de titularidad pública. De este modo, se sigue el criterio de la Ley 3/1984 -art. 27.e)-, que ya dispuso que los documentos de titularidad privada depositados en archivos de uso público serían consultables en condiciones similares a los documentos de titularidad pública (otra cosa ha sido la praxis real).

En tercer lugar, respecto a los documentos que no se encuentren en archivos integrados en el Sistema, la Ley -art. 66.2- establece que el acceso al resto de documentos de titularidad privada «inscritos en el Catálogo General del Patrimonio Histórico Andaluz» se regirá por las siguientes normas:

a) Las personas propietarias, titulares de derechos o poseedoras de dichos documentos permitirán el acceso a los mismos, previa solicitud por escrito, precisa y pormenorizada, salvo cuando su consulta suponga una intromisión en el derecho a la intimidad personal y familiar o a la propia imagen. Debe recordarse que en otro lugar la Ley -art. 21.1.c)- obliga a los titulares o poseedores de estos documentos a permitir el acceso a los documentos, previa solicitud razonada, para su consulta, estudio o investigación, en los términos que regulan la presente ley y la legislación específica que le sea de aplicación. 
Como puede verse, a la solicitud se le exige que sea razonada, precisa y pormenorizada.

b) La persona propietaria, titular de derechos o poseedora de los documentos podrá depositarlos (depósito voluntario) temporalmente en un archivo del Sistema para facilitar el acceso a los mismos -también en este sentido art. 21.1.c)-115.

c) La denegación del acceso tendrá que formularse por escrito motivadamente para que la persona interesada pueda comunicar esta circunstancia a la consejería con el fin de que, en su caso, adopte las medidas previstas en esta ley ${ }^{116}$. Así, debe recordarse que la Ley prevé que cuando no se garantice el acceso de los documentos constitutivos del Patrimonio Documental de Andalucía inscritos en el Catálogo General del Patrimonio Histórico Andaluz, la consejería requerirá a las personas propietarias, titulares de derechos o poseedoras de los mismos la adopción de medidas necesarias para subsanar la situación - art. 23.1-, disponiendo además de la posibilidad de ordenar el depósito (forzoso) de los documentos afectados en un archivo público -art. 23.2-.

Las previsiones de la Ley son razonables, y mejoran lo establecido en la Ley 3/1984, la cual se limitó a disponer que los propietarios de archivos de titularidad privada, que no sean de uso público, establecerán discrecionalmente el acceso a ellos, y comunicarán a la Consejería de Cultura de la Junta de Andalucía las circunstancias para la consulta de sus fondos documentales, que estará garantizada en todo caso - art. 30-. Sin embargo, no se entiende por qué se limitan estas normas a documentos constitutivos del Patrimonio Documental de Andalucía inscritos en el Catálogo General del Patrimonio Histórico Andaluz. Sobre todo, si se tiene presente que la LPHE - art. 52.4- establece la obligación de permitir a los investigadores el estudio de los bienes del patrimonio documental, obligación que puede ser sustituida por la Administración competen-

115 Así, el Decreto 97/2000 dispuso que la Consejería de Cultura podrá acceder a la constitución de un depósito o la microfilmación de los documentos o cualesquiera otras medidas que permitan el acceso a los documentos - art. 91.3-. Se trata, asimismo, de una medida extendida en la legislación autonómica: por ejemplo, Ley de Extremadura 2/2007 - art. 24-.

${ }^{116}$ El Decreto 97/2000 dispuso que en el caso de que la intervención de la Consejería de Cultura sea solicitada por persona distinta del titular de los documentos, se otorgará a éste un plazo de quince días a efectos de que manifieste lo que a su derecho convenga - art. 91.2-. Entendemos que este trámite sigue vigente, pero, además, se plantea la ubicación del informe preceptivo de la Comisión Andaluza de Valoración y Acceso a los Documentos previsto en el artículo 31.3. Así, pues, se evidencia la necesidad de un desarrollo reglamentario que contenga las precisiones necesarias para articular los derechos de las partes en presencia (ciudadano que solicita la consulta y titular del archivo privado) así como la función tutelar de la Administración. 
te, mediante el depósito temporal del bien en un archivo, biblioteca o centro análogo de carácter público que reúna las condiciones adecuadas para la seguridad de los bienes y su investigación.

\section{CONGLUSIONES}

La Ley 7/2011, de 3 de noviembre, de Documentos, Archivos y Patrimonio Documental de Andalucía, culmina un proceso de renovación de la legislación andaluza de patrimonio cultural emprendido con la aprobación de la Ley 16/2003, de 22 de diciembre, del Sistema Andaluz de Bibliotecas. Pero también se enmarca en una tendencia iniciada en otras Comunidades Autónomas de aprobación de leyes sobre archivos de segunda generación. Y en el contexto de estas nuevas leyes autonómicas sobre archivos, aun cuando hay innegables elementos comunes (como la introducción de la idea de gestión documental integrada, o la relevancia concedida el derecho de acceso a los documentos), la Ley 7/2011 presenta caracteres propios, si bien no puede ya calificarse, a diferencia de la Ley 3/1984, como una ley pionera.

Esta identidad propia de la Ley 7/2011 viene en gran medida determinada por la influencia en su diseño de dos normas propias del ordenamiento andaluz, como son el Decreto 97/2000, de 6 de marzo, cuya influjo es innegable en la ordenación del Sistema Archivístico de Andalucía, y la Ley 14/2007, de 26 de noviembre, de Patrimonio Histórico de Andalucía, que ha influido notablemente en la ordenación del Patrimonio Documental de Andalucía, así como en el diseño de los órganos competentes del Sistema Archivístico de Andalucía.

Desde el punto de vista formal, se aprecian en la Ley 7/2011 algunas deficiencias. Así, en ocasiones, se fuerzan en exceso los conceptos legales: como sucede al calificar a los archivos de titularidad estatal y gestión autonómica como archivos «de la Junta de Andalucía». O cuando se diferencia, de un lado, el Archivo del Parlamento de Andalucía, y de otro, los archivos de titularidad y gestión de la Junta de Andalucía (como si el Archivo del Parlamento de Andalucía no fuese un archivo de titularidad y gestión de la Junta de Andalucía). También es confusa la Ley cuando, por ejemplo, declara que son archivos públicos los que custodian y sirven los documentos, generados por las entidades públicas en el ejercicio de sus competencias -art. 34.1-, para seguidamente añadir que son archivos públicos los de los órganos y entidades relacionados en el artículo 9, precepto que engloba entidades jurídico privadas. 
Asimismo, algunas decisiones sistemáticas son discutibles, como sucede al diferenciar en dos capítulos los documentos de titularidad pública y el Patrimonio Documental de Andalucía, cuando lo cierto es que todos los documentos de titularidad pública, sin excepción, forman parte del Patrimonio Documental de Andalucía, y ello a pesar del desafortunado tenor literal de algún precepto - art. 10.1-. Igualmente, es discutible la ubicación sistemática del Censo de Archivos de Andalucía en el Sistema Archivístico, pues es perfectamente posible que existan archivos de titularidad privada incluidos necesariamente en el Censo de Archivos de Andalucía por custodiar documentos integrantes del Patrimonio Documental de Andalucía, pero que, sin embargo, no estén integrados en el Sistema Archivístico de Andalucía, pues tal integración es exclusivamente voluntaria. Asimismo, tal vez habría sido más clarificador vincular la gestión documental al régimen de los documentos de titularidad pública.

Desde el punto de vista del contenido, dejando al margen alguna inexactitud en el concepto de Patrimonio Documental de Andalucía (como la referida al elemento de la ubicación en la Comunidad Autónoma, el cual no es exigible en todo caso), la delimitación de los documentos de titularidad pública integrantes del Patrimonio Documental de Andalucía coincide en lo sustancial, con una terminología más actualizada, con la ya establecida en la Ley 3/1984, pues la única novedad relevante es la inclusión de las entidades jurídico-privadas integrantes del sector público. Además, se mantiene en coherencia con la LPHE el criterio según el cual forman parte del Patrimonio Documental los documentos de titularidad pública «de cualquier época, recogidos o no en archivos». Asimismo, el régimen jurídico de los documentos de titularidad pública presenta escasas novedades en relación con lo ya establecido en la Ley 3/1984 o en la LPHE (salvo la ordenación de la transferencia de documentos por traspaso de funciones o por extinción de órganos, entes u organismos públicos).

En materia de Patrimonio Documental de Andalucía, respecto a los documentos de titularidad privada, la Ley 7/2011 mantiene la triple distinción establecida en la Ley 3/1984, a la que añade una cuarta categoría.

- Documentos de más de cuarenta años de antigüedad en poder de entidades sociales: la Ley 7/2011 mantiene el plazo de los cuarenta años de la LP$\mathrm{HE}$, si bien añade que se trate de documentos ubicados en la Comunidad Autónoma.

- Documentos de más de 100 años de antigüedad en poder de cualquier persona: se mantiene también el plazo de los cien años de la LPHE. Ahora bien, la Ley /2011 limita la integración en el Patrimonio Documental de 
Andalucía a los documentos «que a la entrada en vigor de esta Ley tengan una antigüedad igual o superior a cien años», limitación que estimamos contradice lo establecido en la LPHE.

- Documentos incluidos en el Inventario de Bienes Reconocidos del Patrimonio Documental de Andalucía: inspirado en la Ley 14/2007 de Patrimonio Histórico de Andalucía, este registro viene organizar la potestad, ya contemplada en la Ley 3/1984, de integrar en el Patrimonio Documental documentos que no alcancen la antigüedad establecida en los dos supuestos anteriores.

- Documentos inscritos en el Catálogo General del Patrimonio Histórico Andaluz: se trata de una novedad tomada de la Ley 14/2007, y que puede recaer sobre cualquier documento, tanto los de las dos primeras categorías como documentos que no alcancen la antigüedad indicada y no hayan sido incluidos en el Inventario.

Respecto al régimen jurídico del Patrimonio Documental de Andalucía, de las cuatro categorías reseñadas, la Ley 7/2011 se limita, prácticamente, a proteger una única categoría: los inscritos en el Catálogo General del Patrimonio Histórico Andaluz. Giertamente es razonable el propósito del legislador (exposición de motivos) de establecer regímenes jurídicos diferenciados para el Patrimonio Documental de Andalucía y los documentos inscritos en el Catálogo General del Patrimonio Histórico Andaluz. Sin embargo, lo cierto es que el régimen de protección ordenado en la Ley se contrae casi exclusivamente a los documentos inscritos en el Catálogo General del Patrimonio Histórico Andaluz. Curiosamente, se trata de una ordenación, en buena medida innecesaria, pues los bienes del Catálogo General del Patrimonio Histórico Andaluz ya cuentan en la Ley 14/2007 de normas equivalentes a las establecidas en la Ley $7 / 2011$ (salvo en relación con los traslados), por lo que no precisan de esta protección específica.

De este modo, la ordenación legal del Patrimonio Documental de Andalucía plantea, a nuestro modo de ver, tres cuestiones:

- ¿Es legítimo que una Comunidad Autónoma excluya del Patrimonio Documental autonómico bienes integrados en el Patrimonio Documental Español por la Ley básica? Entendemos que no: la ley autonómica puede proteger bienes más allá de los integrados en el Patrimonio Histórico Estatal, pero no puede excluir de su protección a bienes pertenecientes al mismo. 
- Incluso desde la propia perspectiva de la Ley autonómica, ¿es legítimo que brinde protección sólo a una parte (además, reducidísima) de los bienes integrantes del Patrimonio Documental de Andalucía definido por la propia Ley? Parece razonable establecer una graduación en la protección, pero no parece coherente declarar bienes integrantes del Patrimonio Documental de Andalucía, pero despojados de protección jurídica. Habrá que entender, al menos, aplicables las reglas de protección ordenadas en la LPHE.

- Y, siguiendo desde la economía de la propia Ley 7/2011, ¿qué sentido tiene crear un instrumento nuevo como el Inventario de Bienes Reconocidos del Patrimonio Documental de Andalucía, que requiere de un procedimiento de inclusión casi tan largo y complejo como el de inscripción en el Catálogo General, pero desprovisto por completo de las ventajas de que gozan los bienes inscritos en el mismo?

En cuanto a los órganos del Sistema Archivístico de Andalucía, la estructura orgánica de la Ley 7/2011 es, en gran medida, continuista con la establecida no ya en la Ley 3/1984 sino en el Decreto 97/2000. De este modo, la nueva Comisión del Sistema Archivístico de Andalucía se corresponde en lo esencial con la anterior (y poco afortunada) Comisión de Coordinación del Sistema de Archivos; y la nueva Comisión Andaluza de Valoración y Acceso a los Documentos se corresponde con la anterior Comisión Andaluza Calificadora de Documentos Administrativos. No obstante, debe destacarse la decidida atribución de competencias en materia de acceso a la Comisión Andaluza de Valoración y Acceso a los Documentos y, en particular, la previsión de un informe preceptivo de este órgano en caso de formulación de recursos o reclamaciones contra las denegaciones del derecho de acceso a los documentos.

Respecto al régimen de los archivos integrados en el Sistema Archivístico de Andalucía, la Ley 7/2011 apenas avanza en la definición de obligaciones. Y esta vaguedad del texto legal es especialmente manifiesta en relación con el personal de los archivos (su suficiencia y competencia profesional), elemento clave para garantizar la calidad del Sistema. Igualmente, en relación con los derechos de los archivos integrados en el Sistema, apenas se encuentra una genérica preferencia en materia de medidas de fomento. De este modo, la Ley no acierta a definir las ventajas de una integración (que es siempre voluntaria) en el Sistema por parte de los archivos privados. Además, la Ley 7/2011 ha omitido toda referencia a la externalización de los archivos públicos y, con independencia de cuál sea la posición que pueda adoptarse ante este fenómeno, no parece que ignorar una realidad tan notoria sea la mejor política para afrontarla. 
En cuanto a la estructura del Sistema Archivístico de Andalucía, la Ley mantiene, en términos generales, la estructura diseñada no tanto en la Ley 3/1984 como en el Decreto 97/2000. No obstante, sí existen algunas novedades reseñables.

En relación con los llamados Archivos de la Junta de Andalucía, dejando de lado la sobrevenida independización del Archivo del Parlamento de Andalucía, debe destacarse una más acabada ordenación de los archivos centrales, con la consagración como tales de los archivos de las Delegaciones Provinciales de las Consejerías. Pero, sobre todo, la gran novedad es la anunciada creación de los archivos provinciales intermedios, que vienen en auxilio de unos saturados Archivos Históricos Provinciales, si bien su implantación efectiva está llena de interrogantes (se prevé un plazo de tres años para aprobar el Plan de Implantación, sin fijar plazo alguno de ejecución).

Respecto a los archivos de las entidades locales de Andalucía, el único avance respecto a lo ya previsto en el Decreto 97/2000 es la disposición según la cual los archivos de las diputaciones provinciales y de los ayuntamientos de municipios con más de 15.000 habitantes deberán estar a cargo de personal con la cualificación y nivel técnico que sea necesario, «de acuerdo con la normativa que resulte de aplicación», lo cual es un pobre remedo de las normas de otras leyes autonómicas que definen el servicio de archivo como un servicio municipal mínimo.

Finalmente, respecto a los archivos de titularidad privada integrados en el Sistema Archivístico de Andalucía, la Ley 7/2011 descarta definitivamente la integración ope legis prevista en la Ley 3/1984 para los archivos subvencionados, integración que no llegó a aplicarse. Se trata de una medida pragmática, pero si la integración será siempre voluntaria, se echa en falta una ordenación más sustantiva de la misma, pues la Ley se limita a determinar (innecesariamente) algún aspecto procedimental.

En materia de gestión documental, todas las aportaciones de la Ley 7/2011 son evidentemente novedosas respecto a la Ley anterior. Destacamos aquí el propósito del legislador de integrar la gestión documental en la gestión administrativa, tratando de imponer un principio de transversalidad de las funciones archivísticas y con él un criterio de responsabilidad compartida, que involucre a los gestores administrativos. Otra cosa será, naturalmente, si la Consejería de Cultura es el centro directivo adecuado para hacer efectivos estos buenos propósitos, quebrando una arraigada cultura administrativa de indiferencia de las unidades de gestión hacia las funciones archivísticas. 
Por último, en materia de acceso a la documentación, es innegable que la Ley 7/2011 aporta sensibles mejoras, entre las que destacan las siguientes:

- Supresión del plazo de treinta años de haber finalizado su trámite o vigencia administrativa como condición general de «consultabilidad pública».

- Supresión de la cláusula en extremo vaga que permitía denegar el acceso cuando pudiera «afectar a los intereses vitales de Andalucía».

- Adaptación más fiel a lo establecido en la LPHE en relación documentos que pudieran afectar a la seguridad de las personas, a su honor, a la intimidad de su vida privada.

- Redacción considerablemente más garantista de la excepción referente a las personas que hayan hubiesen cometido infracciones (ahora penales) contra la seguridad y conservación del Patrimonio Documental.

- Regulación más precisa del acceso a los documentos de titularidad privada constitutivos del Patrimonio Documental de Andalucía no custodiados en archivos públicos.

- Tipificación como infracción grave de la acción consistente en impedir el derecho de acceso de la ciudadanía a los archivos.

No obstante, se echa en falta en la Ley el tratamiento de algunas cuestiones, como el reconocimiento expreso de la comunicación parcial de los documentos, o una redacción más exigente de las limitaciones derivadas del estado de conservación de los documentos. 